
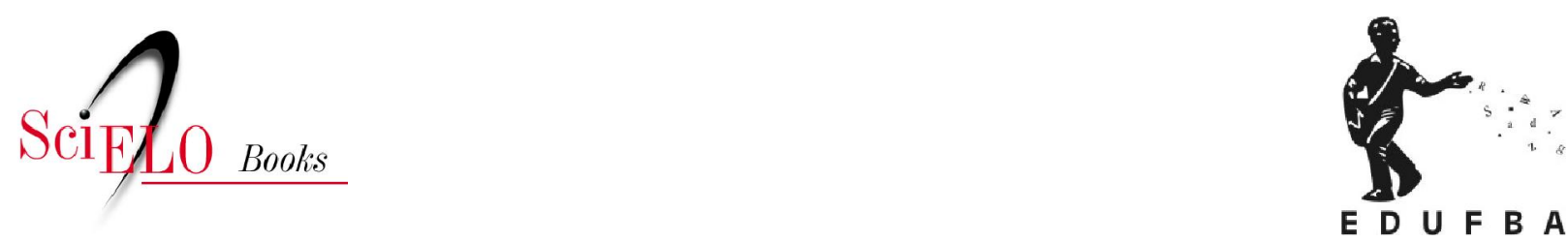

\title{
Arquivologia e patrimônio musical
}

\author{
André Guerra Cotta \\ Pablo Sotuyo Blanco (org.)
}

COTTA, AG., and BLANCO, PS., org. Arquivologia e patrimônio musical. Salvador: EDUFBA,

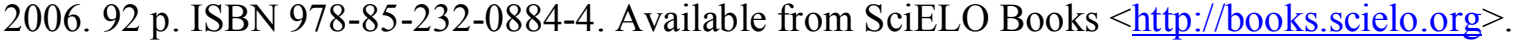

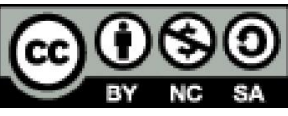

All the contents of this work, except where otherwise noted, is licensed under a Creative Commons Attribution-Non Commercial-ShareAlike 3.0 Unported.

Todo o conteúdo deste trabalho, exceto quando houver ressalva, é publicado sob a licença Creative Commons Atribuição Uso Não Comercial - Partilha nos Mesmos Termos 3.0 Não adaptada.

Todo el contenido de esta obra, excepto donde se indique lo contrario, está bajo licencia de la licencia Creative Commons Reconocimento-NoComercial-CompartirIgual 3.0 Unported. 


\section{ARQUIVOLOGIA E PATRIMÔNIO MUSICAL}


UNIVERSIDADE FEDERAL DA BAHIA

Reitor: Prof. Dr. Naomar Monteiro de Almeida Filho

Vice-Reitor: Francisco Mesquita

ESCOLA DE MÚSICA

Diretor: Prof. Horst Schwebel

PROGRAMA DE PÓS-GRADUAÇÃO EM MÚSICA

Coordenador: Prof. Dr. Ricardo Mazzini Bordini

EDITORA DA UNIVERSIDADE FEDERAL DA BAHIA

Diretora: Flávia M. Garcia Rosa

Conselho Editorial:

Angelo Szaniecki Perret Serpa

Carmen Fontes Teixeira

Dante Eustachio Lucchesi Ramacciotti

Fernando da Rocha Peres

Maria Vidal de Negreiros Camargo

Sérgio Coelho Borges Farias

Suplentes:

Bouzid Izerrougene

Cleise Furtado Mendes

José Fernandes Silva Andrade

Nancy Elizabeth Odonne

Olival Freire Júnior

Sílvia Lúcia Ferreira 


\title{
ARQUIVOLOGIA E PATRIMÔNIO MUSICAL
}

\author{
André Guerra Cotta \\ Pablo Sotuyo Blanco
}

EDUFBA

Salvador, 2006 
(C) 2006 by Programa de Pós-Graduação em Música da UFBA

Projeto Institucional de Pesquisa

"O Patrimônio Musical na Bahia"

(PRODOC-CAPES / PPGMUS-UFBA)

Prof. Dr. Pablo Sotuyo Blanco

\section{Apoio: CAPES}

Sistema de Bibliotecas da UFBA - Biblioteca Central

Instituto de Ciência da Informação - UFBA

Associação dos Arquivistas da Bahia

Biblioteca Central Reitor Macêdo Costa - UFBA

C846 Cotta, André C846

Arquivologia e patrimônio musical / André Guerra Cotta, Pablo Sotuyo Blanco ; organizador e editor Pablo Sotuyo Blanco. - Salvador: Edufba, 2006.

92 p. - (O Patrimônio Musical na Bahia).

ISBN 85-232-0406-7

"Textos apresentados durante o ciclo de palestra homônimo realizado de 16 a 20 de agosto de 2004 na Biblioteca Central "Reitor Macedo Costa".

Apoio: Capes - Sistema de Bibliotecas da UFBA - Instituto de Ciências da Informação da UFBA - Associação dos Arquivistas da Bahia.

1.Música - Arquivos. 2. Patrimônio cultural - Bahia. I. Sotuyo Blanco, Pablo. II. Universidade Federal da Bahia. Escola de Música. III. Título.

$$
\begin{aligned}
& \text { CDU - 78:930.23 } \\
& \text { CDD - } 780
\end{aligned}
$$


Textos apresentados durante o ciclo de palestras homônimo

realizado de 16 a 20 de Agosto de 2004 na Biblioteca Central "Reitor Macedo Costa" 



\section{Sumário}

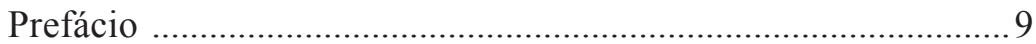

Kátia Maria de Carvalho Custódio

Apresentação

Maria das Graças Ribeiro

Fundamentos para uma arquivologia musical 15 André Guerra Cotta

Perspectivas de integração do patrimônio musical brasileiro 39 André Guerra Cotta

O Patrimônio Musical na Bahia:

Diagnóstico, Estratégias e Propostas 57 Pablo Sotuyo Blanco

Acervo Curt Lange - UFMG:

apresentação e perspectivas 75 André Guerra Cotta 



\section{Prefácio}

Com o objetivo de realizar buscas metodológicas concernentes ao passado musical brasileiro, o projeto "O Patrimônio Musical na Bahia", compreende a arquivologia musical como um campo de conhecimento que reúne seus conceitos e técnicas com o fim de atender as necessidades específicas relativas à organização de acervos ligados à música, compreendendo manuscritos, impressos, discos e documentos tradicionais como cartas e missivas.

A pesquisa documental, notadamente na área de musicologia histórica tem seus fundamentos na musicologia positivista do século XIX e que se transformaram ao longo do século seguinte. Entretanto, desde meados do século XVIII já existiam trabalhos dedicados a descrição e a catalogação de fontes no campo da música. No Brasil, a pesquisa documental tem sua origem nos trabalhos de Curt Lange que formou uma importante coleção de manuscritos musicais das cidades mineiras produzidos nos séculos XVIII e XIX.

Vale ressaltar que a pesquisa acaba por proporcionar a aproximação entre patrimônio musical e arquivologia. Teoria e técnicas arquivísticas se consolidam reafirmando a necessidade de organização de documentos musicais. Neste sentido, o campo conceitual se firma na Ciência da Informação, Arquivologia, História e Musicologia em uma perspectiva interdisciplinar.

A pesquisa se apóia em princípios que permitem a produção de teorias que orientem o pensamento científico, sendo vista a comunicação da informação como um processo social e humano e que não pode estar dissociada da pesquisa.

A pesquisa musical na sociedade atual revela novos paradigmas que vão redimensionando os limites da pesquisa já que a valorização desse patrimônio cultural sempre foi negligenciado, refletindo-se na ausência de políticas públicas adequadas.

A partir da segunda metade do século XIX ocorrem transformações provenientes do uso de novos suportes para a informação arquivística e que incorporam novos princípios de gestão de documentos, permanecendo inalterado o conceito de arquivo, ressaltan- 
do-se a função social de responsabilidade da gestão e acessibilidade aos registros mediante técnicas especificas.

Resgata-se a noção de patrimônio histórico e cultural em que o papel do Estado se estabelece direcionado para arquivos, bibliotecas e museus. Sendo que o arquivo, como fonte de informação e de conhecimento, enfatiza os valores primário e secundário do documento, respectivamente voltados para os aspectos concernentes ao gerenciamento e ao uso.

Contudo, o acesso às fontes de informação arquivísticas no Brasil é de grande complexidade, necessitando de políticas públicas eficientes. Vale ressaltar, a criação do Conselho Nacional de Arquivos - CONARQ, que bem formulado preserva as reais necessidades de definição de políticas nacionais. Na era eletrônica, visualizase uma significativa contribuição de tecnologias e de aparecimento de novos suportes eletromagnéticos e eletrônicos e, também, da comunicação à distância que amplia as possibilidades de transmissão da informação.

As Tecnologias de Informação e de Comunicação - TICs, redimensionam as possibilidades dos processos metodológicos e da gestão do documento. Neste sentido, o crescimento de conhecimentos na área de música permite o resgate da própria historia da musica brasileira e do arquivo porque aprofunda o uso de técnicas no campo musical. A aproximação entre música e arquivologia contribui para a aparição de novos conceitos, metadados e técnicas que viabilizam a disseminação da informação adequadamente.

Sensível às mudanças na área, o presente trabalho põe em destaque duas vertentes: da pesquisa e da preservação de documentos.

A presente obra intitulada Arquivologia e Patrimônio Musical contribui para a história da música e do uso de tecnologias, o que implica no resgate da memória musical brasileira, pouco conhecida no período colonial, introduzindo uma visão crítica em relação às metodologias pertinentes.

Deste modo, percebe-se ser este livro um eficiente meio de disseminação de informação e de conhecimento que resulta da atividade dos pesquisadores e, conseqüentemente, desta Universidade.

Os autores e pesquisadores, André Guerra Cotta e Pablo Sotuyo Blanco sensíveis à necessidade de organização de documentos e de 
arquivos na área de música, buscaram na arquivologia, as técnicas, os processos necessários, criando a oportunidade de desenvolvimento de uma pesquisa inter-institucional, entre a área de Música e a de Ciência da Informação (Arquivologia), que, articulados, podem ampliar conhecimentos, técnicas e tecnologias em uma sociedade que assiste à inclusão de novos suportes materiais. Acesso e uso da informação subentendem a assimilação da informação por parte do leitor, produzindo mudanças e levando-os a outros conhecimentos.

Esta aproximação proporciona a construção de procedimentos metodológicos e de teorias legitimadas e, portanto, evitando formulações equivocadas por desconhecimento de um "corpus" teórico pertinente. Um livro como este, impresso ou eletrônico, resultante da pesquisa acadêmica e surgido a partir do ciclo de palestras homônimo, que também proporcionou o aprendizado e que contou com a participação de docentes e discentes, deve ser estimulado como ferramenta de construção da sociedade do futuro.

Prof ${ }^{\mathrm{a}}$. Katia Maria de Carvalho Custódio Diretora do Instituto de Ciência da Informação da Universidade Federal da Bahia 



\section{Apresentação}

Ser convidada para apresentar o livro Arquivologia e Patrimônio Musical, resultado do ciclo de palestras homônimo realizado pelos professores André Guerra Cotta (Universidade Federal de Minas Gerais - UFMG) e Pablo Sotuyo Blanco, em agosto de 2004, é motivo para a conjunção de três sentimentos profundos: satisfação, emoção e prazer.

Satisfação em ter servido em mais de uma maneira à comunidade científica baiana e brasileira dando condições para a realização do referido ciclo de palestras. Emoção de ver que os esforços nunca são em vão, pois a semente do conhecimento, quando plantada com critério e bom senso, tende a desenvolver suas capacidades até o seu limite. E, finalmente, prazer de poder dar testemunho do fruto concreto de um esforço conjunto que se sabe especial, momento que marca indelevelmente o percurso de um desses raros atores que a Bahia ganha de tempo em tempo.

Uruguaio de nascença, baiano por opção, Pablo, na sua fértil inquietação de recém-doutor selecionado pelo Programa de Pós-Graduação em Música da Universidade Federal da Bahia - UFBA, para levar à frente o Projeto Institucional de Pesquisa "O Patrimônio $\mathrm{Mu}$ sical na Bahia”, buscava rumos e soluções para os problemas que atingiam os arquivos de música.

Foi então que procurou a Biblioteca Central Reitor Macedo Costa, propondo-nos iniciar um caminho de parceria, de discussão e de transformação da consciência para com o patrimônio musical em nosso Estado.

Assim, a sua proposta de realizar um ciclo de palestras focando os problemas e as soluções existentes e possíveis no âmbito arquivístico baiano e nacional foi muito bem recebida não apenas pela Biblioteca Central, mas pelo Sistema de Bibliotecas da UFBA como um todo.

Com o intuito de garantir a abrangência federal que caracteriza as suas ações, Pablo decidiu convidar o musicólogo André Guerra Cotta, mestre em Ciência da Informação pela UFMG e atual Pesquisador Coordenador do Acervo Curt Lange, daquela Universida- 
de Federal, medida que se confirmou como acertada e louvável, combinando assim num mesmo ciclo, dois profissionais capazes e comprometidos com o fortalecimento da novíssima arquivologia musical brasileira e as suas ferramentas específicas.

A qualidade do resultado está, agora, ao alcance de você, caro leitor. Este é apenas o primeiro de uma série de livros que os ciclos de palestras subseqüentes organizados por Pablo (cada um deles com convidados externos criteriosamente escolhidos) permitiriam produzir. Embora alguns deles poderiam estar à espera de publicação, preferimos manter a ordem cronológica da sua realização. Como disse Geraldo Vandré “quem sabe faz a hora, não espera acontecer".

Vamos, então, aproveitar esta leitura, colocando este livro como ferramenta de pesquisa e estudo no campo do conhecimento arquivológico e, por que não, biblioteconômico.

Boa leitura!

Maria das Graças Ribeiro

Diretora da Biblioteca Central "Reitor Macedo Costa" 


\section{Fundamentos para uma arquivologia musical \\ André Guerra Cotta}

\section{Introdução}

As relações entre arquivologia e patrimônio musical são provavelmente inusitadas para aqueles que comungam de uma visão mais tradicional da teoria arquivística, associando-a quase que exclusivamente ao tratamento de documentação administrativa produzida pelo Estado ou por grandes empresas. Contudo, uma visão mais aberta da teoria e das técnicas arquivísticas vem recentemente ampliando as possibilidades de sua aplicação no tratamento de arquivos pessoais e de instituições de pequeno porte, sem uma organização administrativa sistematizada, como é o caso, por exemplo, das corporações musicais existentes no interior do Brasil. Por outro lado, tais relações são também inusitadas para a grande maioria dos profissionais da área de música, inclusive aqueles que lidam diretamente com os acervos musicais, uma vez que a própria teoria arquivística é pouquíssimo conhecida e divulgada, e portanto seus conceitos e técnicas não são sequer considerados. Daí a importância deste evento, para o qual gostaríamos de contribuir trazendo o conceito de arquivologia musical. Denominamos como arquivologia musical um campo de conhecimento que alia conceitos e técnicas da arquivologia tradicional às necessidades específicas para o tratamento técnico de acervos ligados à música, especialmente no caso de manuscritos musicais, mas também no caso de impressos, discos e até mesmo documentos tradicionais, como cartas missivas.

A pesquisa documental sistemática, tão fundamental para o trabalho do musicólogo, sobretudo na área de musicologia histórica, teve suas bases estabelecidas pela musicologia positivista do século XIX. Embora desde meados do século XVIII já existissem trabalhos voltados para a descrição e catalogação de fontes no campo da música (BROOK, 1997, p. x), tais bases podem ser mais propriamente reconhecidas no Chronologisch-thematisches Verzeichniss de 
Ludwig Richter von Köchel (1862) e nos esforços enciclopédicos do Quellen-lexikon de Robert Eitner (1898-1904), iniciativas que consistiram em descrever e sistematizar informações sobre um determinado corpus de documentos musicais: sobre a obra de um determinado compositor, no primeiro caso; sobre as fontes relacionadas a todos os compositores e obras da música ocidental, no segundo. Tais bases foram, é claro, profundamente transformadas no decorrer do século XX, culminando, depois de um longo processo histórico, em um projeto de proporção mundial como o Répertoire Internationale de Sources Musicales - RISM, o mais ambicioso projeto de catalogação de fontes musicais já implementado até o momento, iniciado em 1952.

No caso do Brasil, a referência pioneira em termos de pesquisa documental na área da música encontra-se no trabalho de Francisco Curt Lange (Eilenburg, 1903 - Montevidéu, 1997), que, a partir de meados da década de quarenta do século XX, realizou um trabalho de pesquisa de campo sem precedentes, baseando-se inicialmente em documentos de acervos musicais existentes nas cidades históricas de Minas Gerais, através do qual revelou uma faceta da história da música brasileira até então insuspeitada para os meios acadêmicos e para a intelectualidade da época. Lange publicou diversos estudos, artigos e livros, promoveu concertos e edições da música dos compositores mineiros setecentistas, difundiu-a nas principais instituições culturais e acadêmicas das Américas e da Europa, inaugurando uma linha de pesquisa que ganhou muitos seguidores no Brasil, um número crescente de trabalhos acadêmicos e produções artísticas ao longo das décadas seguintes e que, no princípio do século XXI, está ainda longe de dar seus últimos frutos.

O trabalho de Curt Lange junto aos acervos merece, por si só, tanta atenção quanto têm merecido as obras musicais registradas nos manuscritos que colecionou. Ele formou, através de viagens e de intercâmbio com pessoas ligadas à tradição musical das cidades mineiras, uma coleção de manuscritos musicais produzidos nos séculos XVIII e XIX - desde 1983 sob a guarda do Museu da Inconfidência (Ouro Preto, MG) - que deu fundamentação para os seus estudos e publicações. Geralmente, devido à forte impressão causada pela música ou pela figura lendária em que se converteu o próprio Lange, 
costuma-se negligenciar este aspecto. No contexto em que estamos, porém, é imperativo fazê-lo - e não se trata aqui de questionar a figura de Lange, mas de refletir sobre as bases e os efeitos de sua intervenção sobre os conjuntos documentais. ${ }^{1} \mathrm{O}$ fato de que ele tenha colecionado tais documentos é digno de atenção porque, por mais que se possa considerá-lo aceitável ou justificado, tem conseqüências prejudiciais em termos de acesso à informação.

Para compreender precisamente o que significa colecionar documentos, sejam eles especificamente musicais ou não, é preciso abordar o campo conceitual apropriado - a arquivologia - levandose em conta conceitos das áreas de musicologia, história e ciência da informação, em uma perspectiva interdisciplinar. Para tanto, vejamos alguns conceitos.

\section{Conceitos fundamentais}

É preciso levar em conta que as bases estabelecidas pela musicologia positivista do século XIX sofreram todo um processo de transformação ao longo do século XX, assim como as áreas de

\footnotetext{
${ }^{1} \mathrm{Na}$ versão falada deste trabalho, comentei brevemente, a título de introdução, que em minha graduação em música ressenti a ausência - salvo raras exceções - de tópicos relativos à produção musical brasileira do passado e de uma abordagem sistemática sobre o trabalho de Curt Lange e os acervos musicais brasileiros, o que acabou motivando-me a buscar a área de pesquisa em música e levando-me a participar de iniciativas entre a Escola de Música da UFMG e acervos de cidades mineiras como Diamantina, Santa Luzia e Itabira, que consistiram em minhas primeiras experiências concretas - e, é preciso reconhecer, um tanto empíricas - de tratamento de acervos musicais. Mais tarde, tive a oportunidade de sistematizar conceitos e técnicas em minha dissertação de mestrado na área de Ciência da Informação (COTTA, 2000), sobretudo aqueles ligados ao Répertoire Internacionale de Sources Musicales (RISM) e ao International Standard for Archival Description (general) $\operatorname{ISAD}(G)$, e, nos últimos anos, de colocar muitos deles em prática em projetos ligados ao Acervo Curt Lange - UFMG (Belo Horizonte, MG) e ao Museu da Música (Mariana, MG). É também significativo que as questões conceituais e técnicas ligadas aos acervos musicais têm sido tema constante nos encontros ligados à musicologia brasileira, especialmente nas edições do Encontro de Musicologia Histórica, (Juiz de Fora, 1996-2004), do Simpósio Latino Americano de Musicologia (Curitiba, 1997-2001) e do primeiro evento específico para o tema, o I Colóquio Brasileiro de Arquivologia e Edição Musical - CBAEM (Mariana, 2003).
} 
conhecimento acima mencionadas e a própria noção de ciência. Thomas Kuhn, em sua obra $A$ Estrutura das revoluções científicas (1962), trouxe a noção de paradigma, que o autor define como "realizações científicas universalmente reconhecidas que, durante algum tempo, fornecem problemas e soluções para uma comunidade praticante de ciência" (KUHN, 1996, p. 13). Referenciando-se nela, mostrou como a produção do conhecimento científico passa por processos de ruptura em que os conceitos e a própria visão de mundo dos cientistas são radicalmente modificados em função da emergência de um novo paradigma, contrariando aquele até então vigente. Para Kuhn, as ciências sociais têm um caráter pré-paradigmático (ao contrário das ciências naturais, estas sim paradigmáticas).

O sociólogo Boaventura de Souza Santos (1996, p. 43), por outro lado, afirma que a crise paradigmática pós-moderna levou à necessidade de revisar (ou mesmo de abandonar) esta concepção de um caráter pré-paradigmático das ciências humanas, na medida em que as ciências naturais aproximaram-se das humanidades, revalorizadas justamente por terem resistido à separação sujeito/objeto e por terem preferido a compreensão do mundo à sua manipulação (SANTOS, 1996, p. 44). ${ }^{2}$ Qualquer trabalho científico que se pretenda atual terá que levar em conta tais questões, sobretudo quando se propõe a uma perspectiva transdisciplinar. A transdisciplinaridade implica na compreensão dos conceitos com os quais se opera desde seu contexto teórico original, sem perder sua significação particular e específica, para poder utilizá-los em continuidade com outras áreas de conhecimento. Gernot Wersig, um cientista da informação que se dedica ao estudo dos usos do conhecimento na pós-modernidade, cunhou a noção de interconceitos:

Estes são conceitos que foram algumas vezes trabalhados em disciplinas tradicionais, tendo em cada caso um ponto de vista muito restrito, mas fora das respectivas disciplinas são usados como conceitos comuns, não sendo questionados porque parecem ser tão familiares que pensamos que todo mundo os entenderá $[. .$.$] eles relacio-$

\footnotetext{
${ }^{2}$ Não se pretende aqui aprofundar a noção de paradigma de Kuhn nem as proposições de Santos, mas apenas situar o leitor quanto a questões epistemológicas que têm sua importância neste contexto teórico e convidá-lo a refletir sobre elas.
} 
nam um conjunto de disciplinas tradicionais sem serem entendidos transdisciplinarmente (WERSIG, 1993, p. 237, tradução e grifo nossos). ${ }^{3}$

Como se pode ver na definição de Wersig, muitas das palavras que utilizamos cotidianamente podem ter, em um campo teórico específico, um sentido preciso e diferente do que o nosso senso comum acredita que sejam, mas parecem tão óbvias que jamais as pessoas se questionam se realmente sabem o que significam. Pensemos em algumas das palavras utilizadas na introdução deste trabalho: arquivos, fontes, documentos, coleção... termos aparentemente simples, que não exigem maiores explicações, e às vezes parecem ser até sinônimos, como no caso de arquivo e coleção. Contudo, no campo conceitual da arquivologia, arquivo e coleção são conceitos quase que opostos, são de natureza radicalmente diferente, como procuraremos mostrar. Passemos, então, a alguns conceitos de aplicação prática, que com freqüência são utilizados de maneira interconceitual.

Um conceito fundamental para a construção de nosso edifício teórico, mas que tem implicações práticas significativas, é o de documento:

Documento é qualquer elemento gráfico, iconográfico, plástico ou fônico pelo qual o homem se expressa. É o livro, o artigo [...], a tela, a escultura, [...] o filme, o disco, a fita magnética [...], enfim, tudo o que seja produzido por razões funcionais, jurídicas, científicas, técnicas, culturais ou artísticas pela atividade humana (BELLOTTO, 1991, p. 14, grifo nosso).

Observemos primeiramente que esta definição de documento amplia bastante a noção tradicional, normalmente utilizada para designar apenas os documentos cujo suporte é o papel. Pois, no contexto da arquivologia atual, ao falar de documento estamos falando de quaisquer elementos gráficos, iconográficos, plásticos ou fônicos

\footnotetext{
${ }^{3}$ No original: "These are concepts which sometimes have been tackled by traditional disciplines, in each case a very restricted viewpoint, but outside the respective discipline they are used as common concepts, not being questioned because they seem to be so familiar that we think everybody will understand them. [...] they interrelate a set of traditional disciplines without being understood transdisciplinarly."
} 
- a citação acima menciona discos e fitas magnéticas, o que é particularmente importante no caso de acervos musicais - produzidos pela atividade humana, por razões funcionais, inclusive por razões culturais e artísticas.

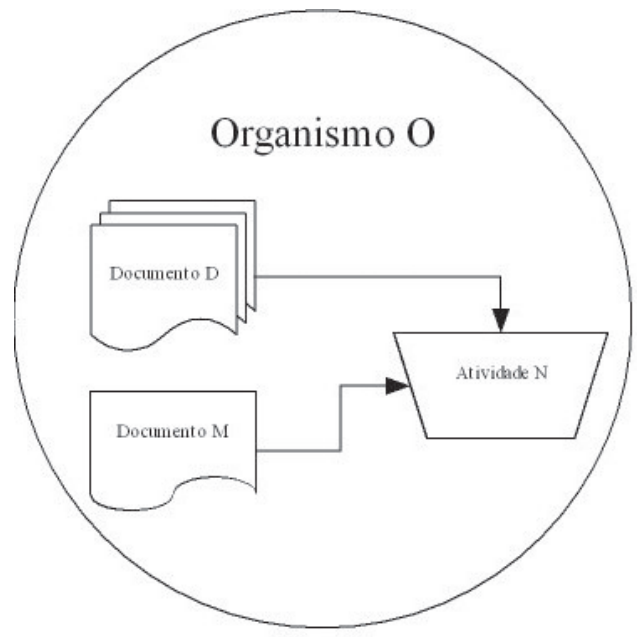

Figura 1 - Relação entre documento, atividade e organismo produtor

Obviamente, esta noção compreende as partituras e partes musicais, mas pode ser ampliada a ponto de abarcar, por exemplo, os próprios instrumentos musicais, que em um determinado contexto podem (e devem) ser efetivamente tratados como documentos. A figura acima mostra como o documento D (um grupo de partes musicais manuscritas da Novena de Nossa Senhora de São Sebastião, por exemplo) relaciona-se com a atividade $\mathrm{N}$ (tocar na Igreja do Rosário durante a referida Novena) desempenhada pelo organismo O (Sociedade Musical Euterpe Itabirana, por exemplo). O Documento M (uma cópia manuscrita da parte de Soprano, refeita por estar a anterior muito gasta) também relaciona-se com a mesma atividade $\mathrm{N}$ e tem, no arquivo do Organismo $\mathrm{O}$, uma relação orgânica com as partes que compõem o documento D. A idéia fundamental é a de que todo documento liga-se a uma dada atividade, realizada por um determinado organismo (produtor ou receptor, indivíduo ou instituição), em função da qual é produzido ou recebido. 
Para compreender totalmente o conceito de documento, é preciso relacioná-lo também a um outro conceito da arquivologia, que é o de ciclo vital dos documentos. Tal como um organismo vivo, os documentos cumprem um ciclo de vida, desde sua produção até o seu eventual desaparecimento. O ciclo vital tem três fases (também chamadas de idades) e inicia-se com a chamada fase corrente, que é a fase durante a qual a atividade a que o documento se liga está em andamento, isto é, o documento está em pleno uso funcional, é utilizado constantemente e, portanto, é mantido próximo aos agentes responsáveis pela execução da atividade. A função a que se liga o documento é importante no sentido de que é ela que dá a medida de seu valor, é ela que fornece elementos para compreender as relações existentes entre o documento e o contexto em que foi produzido ou recebido.

A fase corrente é seguida pela chamada fase intermediária, em que, finalizada a atividade a que se relacionava, o documento não tem mais uso funcional, mas deve ser preservado em função de prazos legais ou de outros aspectos referentes àquela atividade. Mesmo que encerrada a atividade, o documento não pode ser descartado, pois ainda poderá ser necessário consultá-lo. No caso dos documentos administrativos, geralmente são transferidos para um arquivo intermediário e submetidos a uma tabela de temporalidade, que determinará o seu futuro descarte ou recolhimento em um arquivo permanente (do qual falaremos adiante). No caso de documentos musicais, é possível exemplificar as fases corrente e intermediária com o caso acima mencionado, em que uma parte vocal foi recopiada pelo fato de estar muito desgastada: a nova parte passa a dar suporte à função dos músicos e a antiga, não mais utilizada, é mantida no arquivo para consulta (para uma eventual correção, ou mesmo para a produção de novas cópias), e não descartada.

É importante destacar que o descarte de um documento não significa necessariamente a sua eliminação, ou seja, destruí-lo ou simplesmente jogá-lo no lixo. O descarte pode ser feito também através de uma redestinação: embora não seja mais útil para o organismo $\mathrm{O}$, o documento $\mathrm{D}$ pode ser doado ou recolhido por outra instituição, para a qual tem algum valor. Pois a noção de ciclo vital relaciona-se com justamente com os conceitos de valor primário e se- 
cundário dos documentos. Segundo T. R. Schellenberg, um dos arquivólogos mais respeitados no século $\mathrm{XX}$, “chama-se primário o valor que o documento apresenta para consecução dos fins explícitos a que se propõem. Secundários são os que, embora já implícitos no tempo que são gerados os documentos, avultam com o correr dos anos." (SCHELLENBERG, 1959, apud BELLOTTO, 1991, p. 7). O valor primário de um documento, portanto, refere-se ao seu valor de uso funcional, enquanto que o valor secundário é o valor de informação que ele tem. Heloísa Belloto observa, com propriedade, que o valor secundário do documento equivale à abertura de uma "potencialidade informacional infinitamente mais ampla do que a estrita razão funcional de sua geração" (BELLOTTO, 1991, p. 108). Mas é o valor primário de um documento que determinará a duração da fase corrente e a necessidade ou não de mantê-lo em um arquivo intermediário.

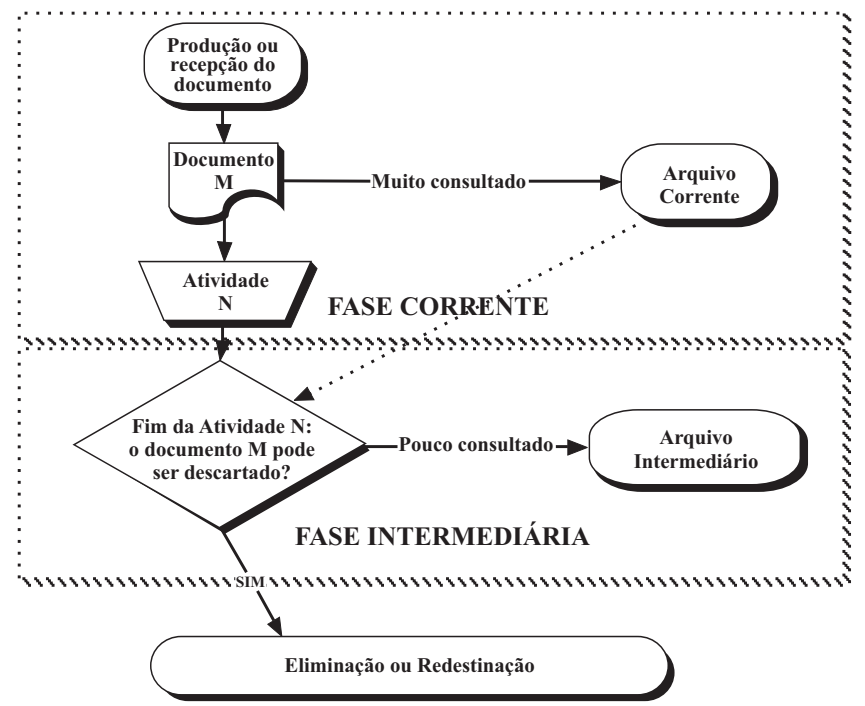

Figura 2 - Fases corrente e intermediária de um documento

A terceira e última fase do ciclo vital é a fase permanente, na qual, estando a atividade funcional concluída e os prazos legais já cumpridos, fica o valor informativo ou probatório do documento, que é recolhido a um local de preservação, o arquivo permanente (BELLOTTO, 1991, p. 5-6). 


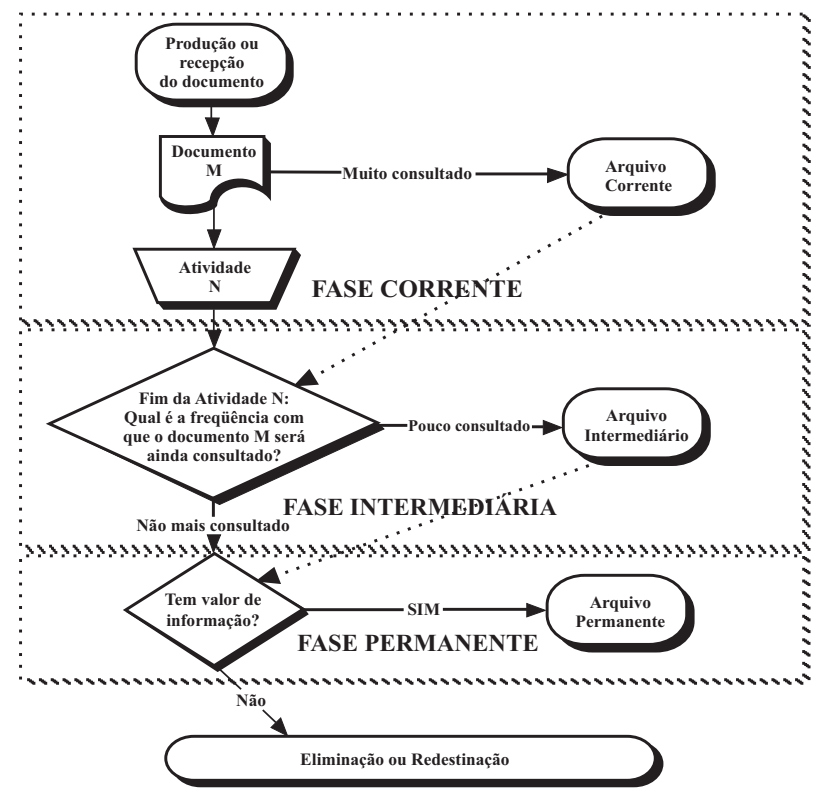

Figura 3 - O ciclo vital do documento

O conceito de arquivo, segundo a terminologia oficial, expressa na própria legislação brasileira, tem dois sentidos:

1. Conjunto de documentos independente da natureza dos suportes, acumulados por uma pessoa física ou jurídica, pública ou privada, ao longo de suas atividades; 2. Instituição ou serviço que tem por finalidade a custódia, o processamento técnico, a conservação e utilização de arquivos (BRASIL, 1996, p. 26).

Temos portanto a palavra arquivo significando ora um conjunto de documentos, como na primeira acepção, ora designando um serviço ou instituição, como na segunda. Para nós, interessa particularmente a primeira, segundo a qual um arquivo é um conjunto de documentos acumulados por um dado organismo, ao longo de suas atividades. Tal processo de acumulação de documentos ocorre naturalmente, como um efeito das atividades a que o organismo - pessoa ou instituição - se dedica, e em função das quais os documentos são produzidos ou recebidos, e realizam o seu ciclo vital, organicamente. Este processo dá origem ao conceito de fundo arquivístico: 
Fundo (fonds) - Conjunto de documentos, independente da forma ou do suporte, organicamente produzido e/ou acumulado por uma pessoa física, família ou instituição no decurso de suas atividades e funções (CONSELHO INTERNACIONAL DE ARQUIVOS, 2000, p. 5).

Este é o conceito fundamental que funda o paradigma da arquivologia moderna e baseia o Princípio de proveniência ou Principio de respeito aos fundos arquivísticos, segundo o qual deve-se

deixar agrupados, sem misturá-los a outros, os arquivos provenientes de uma [...] pessoa física ou jurídica determinada, [assim como] respeitar a ordem estrita em que os documentos vieram [...], a seqüência original de séries (BELLOTTO, 1991, p. 81).

A simples manutenção da integridade de um arquivo, não permitindo a sua fragmentação, tomando-o em sua totalidade, assim como mantendo a ordem original em que os documentos foram acumulados, garante a preservação de relações orgânicas entre os próprios documentos que o constituem, assim como informações relativas ao contexto em que foram acumulados. Por outro lado, a simples desagregação, mesmo que parcial, dos documentos de um dado fundo arquivístico, pode causar um prejuízo irreversível em termos informacionais. Observe-se que a noção de acumulação é importante, pois ela refere-se a um processo não intencional, a um efeito quase que secundário das atividades-fim do organismo que produziu ou recebeu os documentos. Esta noção tem relação estreita com o conceito de proveniência, pois é somente em função das atividades de um dado organismo que o processo de acumulação pode acontecer, e é precisamente isto que o define como sendo a proveniência dos documentos.

Entendidos os conceitos até aqui delineados, podemos nos deter sobre o conceito de coleção. Uma coleção é uma reunião intencional, consciente e factícia de documentos selecionados a partir de origens diversas, com o fim explícito de reuní-los, sem a observância do princípio de respeito aos fundos, sem a preservação, portanto, de sua organicidade. A Coleção Curt Lange, por exemplo, é o resultado de uma reunião intencional de fragmentos de arquivos, de documentos selecionados que fizeram parte de conjuntos orgânicos, em 
um contexto determinado. Uma vez separados de seus fundos, tais documentos perdem grande parte de seu valor de informação, tal como pedras retiradas displicentemente de um sítio arqueológico.

A prática de colecionar manuscritos musicais, à qual talvez a figura lendária do garimpeiro musical - como foi chamado Lange muitas vezes - tenha servido de estímulo, geralmente implica na seleção de certos documentos sob um determinado critério científico ou artístico, desprezando os documentos restantes, quebrando laços orgânicos e contribuindo para a sua destruição. Temos chamado essa prática de colecionismo e acreditamos que ela deve ser vivamente repudiada, na medida em que implica na fragmentação dos arquivos, contribui para a sua destruição e traz prejuízos em termos de informação. Esta é umas das principais contribuições que a aplicação dos princípios arquivísticos no tratamento de acervos musicais, na preservação, portanto, de parte significativa do patrimônio musical brasileiro.

\section{Patrimônio musical}

Pensar as questões relativas à preservação e ao acesso ao patrimônio musical implica necessariamente em repensar a noção tradicional de patrimônio cultural. Esta noção historicamente relaciona-se ao tão criticado conceito de "patrimônio histórico e artístico nacional", uma vez que, sob a sua bandeira, desde a década de trinta do século passado até muito recentemente, todas as políticas públicas de preservação de patrimônio cultural no Brasil voltaram-se quase que exclusivamente para os bens culturais tangíveis produzidos no período colonial, tais como o patrimônio arquitetônico e a imaginária religiosa, negligenciando sistematicamente outros tipos de manifestação cultural tais como festas, mentalidades, práticas culturais e até mesmo o próprio patrimônio documental (ainda que documentos possam ser considerados como patrimônio material, uma vez que tratase de bens tangíveis).

Mesmo no chamado "período heróico" do SPHAN (GONÇALVES, 2002, p. 49), em que as categorias arte e arquitetura colonial eram tomadas como $o$ patrimônio cultural nacional, a música brasileira dos séculos XVIII e XIX não foi contemplada com políticas de 
preservação. Uma das conseqüências diretas para o patrimônio musical foi a perda de muitos acervos importantes e, ainda hoje, a falta de políticas públicas voltadas para a preservação de acervos musicais é freqüentemente apontada como umas das principais razões que levaram ao colecionismo, muitas vezes alegada como justificativa para ele.

É necessária uma reflexão coletiva sobre as razões que efetivamente levaram à dissociação, por muito tempo existente no senso comum e nas orientações de políticas culturais no Brasil, entre o conceito tradicional de patrimônio cultural e o patrimônio especificamente musical, o que, contudo, extrapolaria os objetivos deste trabalho. Mas cabe uma observação importante: os acervos musicais estiveram, até muito recentemente, em uma espécie de limbo, não sendo considerados, do ponto de vista das políticas públicas, nem patrimônio documental, nem patrimônio cultural.

Muito recentemente, somou-se à noção tradicional de patrimônio cultural o conceito inovador de patrimônio cultural imaterial, que trouxe a possibilidade de tombar bens culturais intangíveis, tais como a culinária, danças, festas populares, diferentes práticas culturais, inclusive, é claro, práticas musicais. Esta nova acepção nos faz observar que, no caso da música, encontramos as duas interfaces: enquanto registrada em documentos, como no caso de manuscritos musicais, a música pode ser considerada como patrimônio material, pois são os documentos bens palpáveis, tangíveis; por outro lado, sabe-se que os documentos são, pois, registros que dão suporte a uma prática cultural que é, esta sim, a sua verdadeira manifestação fenomenológica, que se dá propriamente como música aos sentidos humanos - esta é sua face imaterial. Assim, o patrimônio musical é, ao mesmo tempo, material e imaterial. Dada essa sua situação particular, o patrimônio musical oferece grandes desafios do ponto de vista de sua preservação.

Esta dualidade está presente no processo de tratamento de acervos musicais, aparecendo também na relação entre documento e obra, ou, para utilizar uma terminologia mais atualizada, entre unidades documentais e unidades musicais. Onde começa uma e termina outra? Como se distinguem e como se relacionam? A figura que parece ilustrar da forma mais perfeita essa relação é a Faixa (ou tira) de 
Moebius, cujas faces ora estão no lado externo, ora no lado interno.

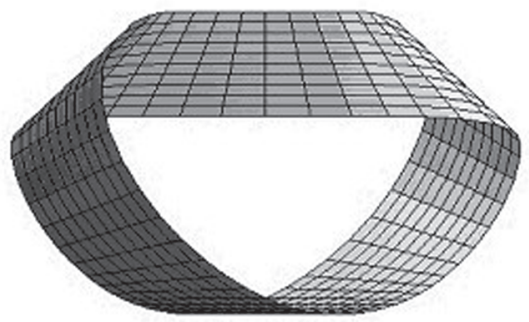

Figura 3 - A Faixa (ou tira) de Moebius

Daí que freqüentemente confunda-se o tratamento técnico de documentos com a catalogação de obras musicais, o que dá margem a muitos equívocos e pode levar à perda de informações preciosas para a pesquisa. A arquivologia musical pode, através dos conceitos apresentados, de alguns processos básicos de tratamento técnico e de instrumentos bem definidos, ajudar a evitar tais equívocos.

\section{Processos básicos}

Alguns dos processos técnicos que o arquivista implementa são fundamentais para garantir uma destinação adequada aos documentos, assim como uma maior racionalidade no seu processamento desde a fase corrente, quando ainda é utilizado, até a fase permanente, ou seja, em todas as etapas de seu ciclo vital. São eles a gestão documental, a avaliação, a transferência e o recolhimento.

A gestão documental se realiza através de um conjunto de procedimentos para o tratamento de todos os documentos de um dado organismo ainda na fase corrente, desde sua origem, sob normas específicas para sua produção, classificação, circulação e posterior arquivamento permanente ou descarte. Uma vez que lida com os documentos que futuramente serão considerados de valor permanente, é fundamental para a pesquisa, e aplica-se aos arquivos de orquestras, coros, corporações musicais, escolas, editoras, etc, mas também aos arquivos pessoais de regentes, compositores, instrumentistas e editores. É a gestão adequada dos documentos correntes de hoje que garantirá a plenitude do seu potencial informacional no futuro. 
A avaliação é "o processo pelo qual se determina o valor arquivístico de um conjunto de documentos" (CONSELHO INTERNACIONAL..., 2000, p. 04). Ela é importante em todas as fases do ciclo vital dos documentos, pois é através dela que se pode definir, em cada fase, a destinação dos documentos: transferência para um arquivo intermediário, recolhimento a um arquivo permanente ou descarte. A avaliação exige uma análise institucional ou um estudo biográfico do organismo produtor e deve ser feita necessariamente por uma comissão interdisciplinar: não é o ponto de vista isolado de um especialista, apenas, que poderá determinar os valores primários e secundários de todos os documentos de uma determinada proveniência.

A transferência é operação de retirar do local original em que foram acumulados aqueles documentos que já não têm uso corrente, mas que não devem ser descartados, acomodando-os em um arquivo intermediário, onde permanecerão disponíveis para a consulta. É fundamental para evitar o descarte sem critérios, assim como para preparar o recolhimento a um arquivo permanente.

O recolhimento é a operação de guardar os documentos que já não tem uso corrente mas revestem-se de valor de informação (ou valor secundário) em um arquivo permanente. É recomendável que o recolhimento seja realizado seguindo procedimentos simples, sem operações dificultosas e complexas; que assegure a fácil localização e recuperação das informações; que permita a elaboração posterior de instrumentos de pesquisa; e que salvaguarde todas as possibilidades de compreensão, conservando-se sua situação primitiva, dentro dos conjuntos orgânicos (Manuel d'arquivistique, apud BELLOTTO, 1991, p. 90). Em termos de arquivos administrativos, Heloísa Bellotto distingue, na prática:

1. O Recolhimento sistemático, regular, organizado, quer quanto às datas, quer quanto à apresentação do material vindo do arquivo intermediário;

2. O recolhimento que é revestido de uma certa regularidade, mas feito diretamente dos arquivos correntes aos arquivos finais, quando ultrapassados os limites do uso primário; 
3. O recolhimento 'selvagem', isto é, quando grandes massas aleatórias são literalmente descarregadas nos arquivos permanentes, sem obediência a critérios técni$\cos$ (BELLOTTO, 1991, p. 89).

Este "recolhimento selvagem" dá origem ao que comumente chama-se de "arquivos mortos", nos quais os documentos são simplesmente abandonados sem qualquer cuidado técnico tanto no que diz respeito à sua conservação, como no que diz respeito ao tratamento do ponto de vista da informação.

O arranjo

é uma operação ao mesmo tempo intelectual e material: organizar os documentos uns em relação aos outros; as séries, umas em relação às outras; os fundos, uns em relação aos outros; dar número de identificação aos documentos; colocá-los em pastas, caixas ou latas; ordenálos nas estantes (BELLOTTO, 1991, p. 87).

É o arranjo que revela a organicidade, as relações significativas entre as unidades documentais que compõem um determinado fundo arquivístico, que fundamenta a sua descrição. $\mathrm{O}$ arranjo deve levar em conta: a) a proveniência; b) a história ou biografia do organismo produtor; c) as origens funcionais dos documentos; d) o conteúdo; e) os tipos de material.

A descrição, uma importante atividade desempenhada no processo de tratamento de acervos, mas que freqüentemente é colocada à frente dos passos anteriores, consiste na

elaboração de uma acurada representação de uma unidade de descrição ${ }^{4}$ e de suas partes componentes, caso existam, por meio da extração, análise, organização e registro de informação que sirva para identificar, gerir, localizar e explicar documentos de arquivo e o contexto e o sistema de arquivo que os produziu. Este termo também se aplica ao produto desse processo (CONSELHOINTERNACIONAL..., 2000, p. 4).

É a descrição que irá apresentar ao pesquisador os valores secundários dos itens documentais, que irá difundir o conteúdo infor-

\footnotetext{
${ }^{4}$ Unidade de descrição (unit of description) - Documento ou conjunto de documentos, sob qualquer forma física, tratado como uma unidade, e que, como tal, serve de base a uma descrição particularizada (CONSELHO..., 2000, p. 6).
} 
macional dos arquivos através dos instrumentos de busca (também chamados de instrumentos de pesquisa) e está diretamente ligada à acessibilidade do material.

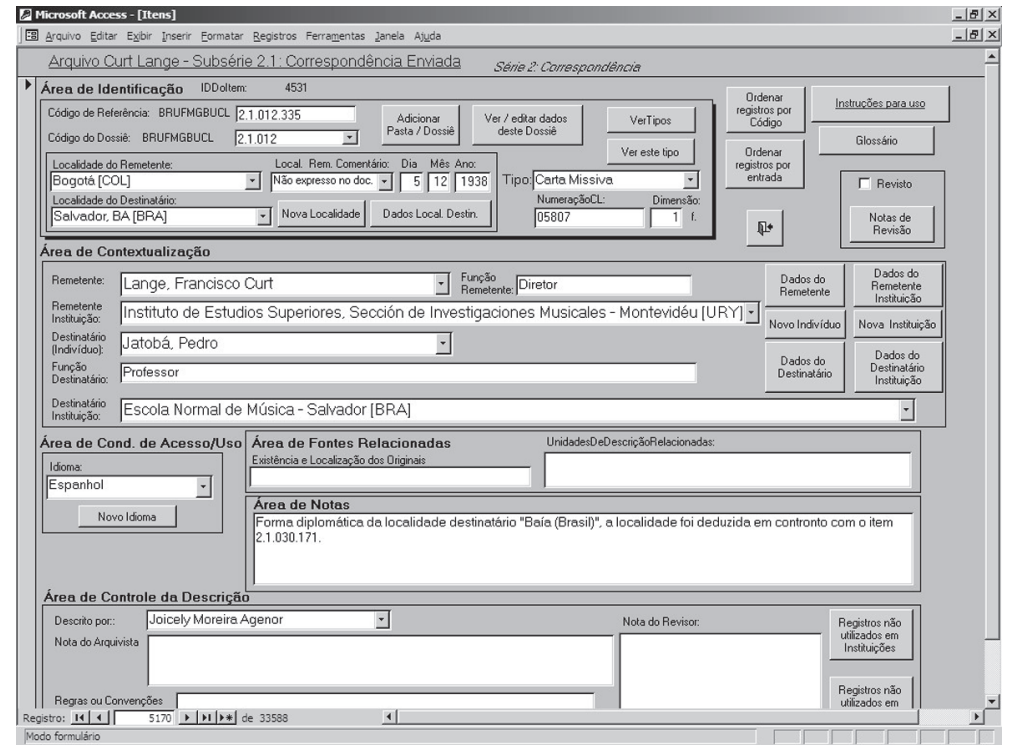

Figura 4 - Tela de Base de dados baseada na $\operatorname{ISAD}(\mathrm{G})$ do Acervo Curt Lange - UFMG

A Norma Geral Internacional de Descrição Arquivística - abreviada como $\operatorname{ISAD}(\mathrm{G})^{5}$ - é constituída por sete áreas, pensadas para identificar e contextualizar cada unidade de descrição, dar elementos para avaliar a sua relevância, conhecer as condições de acesso, entre outras finalidades. São elas: 1. Área de identificação (destinada à informação essencial para identificar a unidade de descrição); 2. Área de contextualização (destinada à informação sobre a origem e custódia da unidade de descrição); 3 . Área de conteúdo e estrutura (destinada à informação sobre o assunto e organização da unidade de descrição); 4. Área de condições de acesso e de uso (destinada à informação sobre a acessibilidade da unidade de descrição); 5. Área de fontes relacionadas (destinada à informação sobre fontes com

\footnotetext{
${ }^{5}$ Abreviatura derivada do título original da publicação do Conselho Internacional de Arquivos, International Standard for Archival Description (General).
} 
uma relação importante com a unidade de descrição); 6. Área de notas (destinada à informação especializada ou a qualquer outra informação que não possa ser incluída em nenhuma das outras áreas); 7. Área de controle da descrição (destinada à informação sobre como, quando e por quem a descrição arquivística foi elaborada) (CONSELHO..., 2000, p. 2-3). Os elementos mínimos de descrição recomendados pela $\operatorname{ISAD}(\mathrm{G})$ : a) código de referência, b) título, c) data(s) de produção ou data(s) de acumulação dos documentos da unidade de descrição, d) dimensão da unidade de descrição, e) nível de descrição, e f) nome do organismo produtor (CONSELHO..., 2000, p. 2).

Uma das recomendações da $\operatorname{ISAD}(\mathrm{G})$ é a chamada descrição multinível. Ela é assim explicada nessa normativa:

Se o fundo como um todo estiver sendo descrito, ele deverá ser representado numa só descrição, utilizando-se os elementos descritivos como mencionado na seção 3 deste documento [Seção que traz os elementos de descrição]. Se é necessária a descrição das suas partes, estas podem ser descritas em separado, usando-se igualmente os elementos apropriados da seção 3. A soma total de todas as descrições assim obtidas, ligadas numa hierarquia [...] representa o fundo e as partes para as quais foram elaboradas as descrições. Para as finalidades destas regras, tal técnica de descrição é denominada descrição multinível (CONSELHO..., 2000, p. 7).

A descrição multinível baseia-se em quatro regras. A primeira recomenda uma descrição do geral para o particular, com o objetivo de "representar o contexto e a estrutura hierárquica do fundo e suas partes componentes":

No nível do fundo, dê informação sobre ele como um todo.

Nos níveis seguintes e subseqüentes, dê informação sobre as partes que estão sendo descritas. Apresente as descrições resultantes numa relação hierárquica entre a parte e o todo, procedendo do nível mais geral (fundo) para o mais particular (CONSELHO..., 2000, p. 7).

O nível mais amplo da hierarquia arquivística é o fundo, que, de acordo com as suas características próprias, relacionadas à biografia ou história do organismo produtor e às ocupações ou atividades 
que desempenhou, pode dividir-se em níveis menores, as séries, subséries, dossiês e finalmente itens documentais. ${ }^{6}$ As demais regras orientam a fornecer informação relevante para o nível de descrição, observando a não repetição de informação, com o objetivo de representar com rigor o contexto e o conteúdo da unidade de descrição, evitar redundância de informação em descrições hierarquicamente relacionadas, assim como explicitar a relação entre descrições, identificando o nível de descrição e relacionando, sempre que for possível, cada descrição à sua mais próxima e superior unidade de descrição.

Existem normas específicas para a descrição de manuscritos musicais, como as Rules for cataloguing music manuscripts (GÖLLNER, 1975), publicadas pela - International Association of Music Libraries - IAML e as normas do Repertoire Internacionale de Sources Musicales - RISM (RÉPERTOIRE INTERNATIONAL DES SOURCES MUSICALES, 1996). Enquanto as primeiras são regras voltadas para a produção de fichas catalográficas e trazem uma orientação de cunho marcadamente biblioteconômico, as normas do RISM são voltadas para uma descrição detalhada das fontes musicais manuscritas. Não cabe nos objetivos desta palestra aprofundar em nenhuma dessas normativas, mas podemos observar que os elementos mínimos de descrição recomendados pelo RISM (Kurt Dorfmüller):

a) Nome do autor (normalizado)

b) Título uniforme e forma musical

c) Título próprio

d) Manuscrito (autógrafo, se for o caso) ou impresso

e) Designação do tipo de documento (partitura, redução, livro de coro, etc.)

f) Incipit musical

g) Nome da biblioteca ou arquivo, cidade e país / assinatura.

É importante observar, contudo, que, nenhuma das normas de descrição de fontes musicais acima mencionadas destinam-se a ori-

\footnotetext{
${ }^{6}$ Esta terminologia varia de idioma para idioma. Para mais detalhes, conferir em Cotta (2000, p. 67).
} 
entar o tratamento técnico de acervos, sobretudo se tem natureza arquivística. Talvez a maior contribuição da arquivologia musical seja a possibilidade de criar estratégias para a organização e o tratamento de acervos de manuscritos musicais, observando-se cuidadosamente os preceitos arquivísticos e os problemas específicos postos pela musicologia, sem perder de vista questões relacionadas às tecnologias da informação. Tais estratégias passam, necessariamente, pela discussão coletiva e pelo estabelecimento de diretrizes a serem adotadas pela comunidade de pesquisa. Alguns dos pontos a serem discutidos e estabelecidos, pela sua importância, são:

a) o estabelecimento de uma terminologia transdisciplinar comum;

b) a distinção entre item documental e unidade musical;

c) critérios para identificação de grupos e conjuntos de manuscritos musicais;

d) estudo de formas e gêneros especificamente encontrados no Brasil;

e) estudo de funções relacionadas ao fazer musical (litúrgicas, cívicas, etc);

f) parâmetros para confecção de incipit musicais padronizados,

g) critérios para a individualização de unidades musicais;

h) organologia aplicada ao tratamento de partes instrumentais antigas; e

i) parâmetros técnicos para intercâmbio de informação.

\section{Para concluir}

Para concluir, é preciso frisar que a diferença fundamental entre os tratamentos arquivístico e bibliográfico consiste na observação, por parte do primeiro, do princípio de respeito aos fundos ou princípio de proveniência. Diferentemente, as técnicas de tratamento voltadas para material bibliográfico baseiam-se em critérios abstratos, podendo ser temáticos, alfabéticos, cronológicos, sem observar a proveniência, o contexto e o processo de acumulação do material documental. A aplicação de tais critérios para o tratamento de material arquivístico pode representar danos irreparáveis em termos 
de informação e acesso à documentação. Esta divergência tem reflexos no que diz respeito à metodologia de descrição do material e também na escolha de softwares para o gerenciamento e recuperação ${ }^{7}$ de informação.

É preciso observar que a utilização de uma metodologia arquivística com bases mais sólidas é um fenômeno bastante recente, sobretudo no Brasil. A própria normativa internacional foi publicada há poucos anos, tendo sua primeira edição em 1994, pelo Conselho Nacional de Arquivos. Devido ao caráter incipiente desta metodologia, não são poucas as dificuldades no que diz respeito à sua aplicação prática, inclusive à sua utilização nos sistemas de recuperação de informação estabelecidos.

Consideramos particularmente importante frisar nossa preocupação com o problema do colecionismo, pois ele chegou a se tornar uma prática comum em nosso país e até mesmo a se consolidar como exemplo. São comuns notícias de colecionadores de documentos históricos, retirados de seus fundos arquivísticos e, ainda que retirados de seu contexto, tratados como relíquias de valor histórico. Da mesma forma, são conhecidos casos de colecionadores de manuscritos musicais, obviamente retirados de arquivos de corporações, de músicos ou de famílias, tratados como peças valiosas, garimpadas no trabalho de campo, sem observar o princípio de proveniência.

Chamo a atenção para um falso paralelo, cuja origem pode estar ligada à concepção tradicional a que nos referimos no início, que relaciona arquivos a instituições e coleções a indivíduos. Isso não é verdadeiro, de forma alguma. Existem coleções reunidas por instituições, assim como existem arquivos pessoais. O que diferencia arquivos e coleções não é a natureza do organismo a que se relacionam, mas a natureza do processo de sua formação: arquivos são naturais, organicamente acumulados, coleções são factícias, artificialmente reunidas. Um exemplo de arquivo pessoal tratado adequadamente é o Fundo Glenn Gould, custodiado pela Biblioteca Na-

\footnotetext{
${ }^{7}$ Utilizamos o termo recuperação tal como cunhado por Calvin Mooers em 1951 (information retrieval, no original inglês), ou seja, para designar o acesso à informação em sistemas de comunicação (ARAÚJO, 1994, p. 85).
} 
cional do Canadá (BARRIAULT; JEAN, 1996). Existem coleções que têm, contudo, características importantes que desaconselham a sua dispersão, como no caso da Coleção Tereza Christina Maria, segundo o desejo manifesto pelo próprio Emperador D. Pedro II (CARVALHO, 1994, p. 73) custodiada pela Biblioteca Nacional do Brasil.

Neste sentido, consideramos extremamente necessária a discussão coletiva e o estabelecimento de políticas para o tratamento de acervos musicais no Brasil. A principal diretriz a ser difundida e recomendada, acreditamos, é a observação do princípio de proveniência. Mas é preciso avançar também no sentido de estudar e estabelecer as linhas de custódia de documentos hoje existentes em coleções, realizando um trabalho integrado entre as diversas iniciativas de tratamento técnico de acervos que contém fragmentos de arquivos ou itens dispersos. Além disso, é cada vez mais urgente o estabelecimento de uma ética com relação à preservação do patrimônio musical, para a qual também a arquivologia pode contribuir, como mostram as palavras do arquivista Theodore R. Schellenberg:

Finalmente, se executa pesquisas próprias, deve o arquivista faze-las em caráter não oficial, pois ele é empregado para ser um arquivista, e não um pesquisador. Não deve subordinar seus deveres profissionais a seus interesses particulares de pesquisa. Numa palavra, deve oferecer seu conhecimento sobre os documentos indistintamente, mesmo com sacrifício de seus próprios interesses de pesquisador. (SCHELLENBERG, 1974, p. 322).

(Palestra ministrada em 16 de Agosto de 2004) 


\section{Referências Bibliográficas}

ARAÚJO, V.M.R.H. de. Sistemas de recuperação da informação SRIs. In: Sistemas de recuperação da informação. Rio de Janeiro: 1994. Capítulo 5, p. 84-121.

BARRIAULT, Jeannine; JEAN, Stéphane. La description des archives de musique: un exemple canadien. Fontes Artis Musicae, Madison, v. 43, n.3, p. 274-285, july/sept. 1996.

BELLOTTO, Heloísa Liberalli. Arquivos permanentes: tratamento documental. São Paulo: T.A. Queiroz, 1991. 198 p.

BRASIL. Arquivo Nacional. Resolução nº, de 28 de março de 1996. Diário Oficial [da] República Federativa do Brasil. Conselho Nacional de Arquivos. Brasília, DF, 29 mar. 1996, Seção 1, p.1-29, suplemento ao $n^{\circ} 62$.

BROOK, Barry S., VIANO, Richard. Thematic catalogues in music: an annotated bibliography. 2nd. ed. Stuyvesant: Pendragon, 1997. L, $602 \mathrm{p}$.

CARVALHO, Gilberto Vilar de. Biografia da Biblioteca Nacional: 1807 a 1990. Rio de Janeiro: Irradiação Cultural, 1994. 225 p.

CONSELHO NACIONAL DE ARQUIVOS. ISAD $(G)$ : Norma Geral Internacional de Descrição Arquivística. 2. ed. Rio de Janeiro: Arquivo Nacional, 2001. 110 p. Disponível em: <http:// www.arquivonacional.gov.br/>. Acesso em: 23 out. 2004.

COTTA, André Guerra. O tratamento da informação em acervos de manuscritos musicais brasileiros. 2000. 291 folhas. Dissertação (Mestrado em Ciência da Informação). Escola de Biblioteconomia, Universidade Federal de Minas Gerais, Belo Horizonte, 2000.

EITNER, Robert. Biographisch-bibliographisches Quellenlexikon: der Musiker und Musikgelehrten christlicher Zeitrechnung bis Mitte des neunzehnten Jahrhunderts. 2.aufl. 
Graz: Akademische Druck-U. Verlagsanstalt, 1959-1960. 11 v. $\left(1^{\mathrm{a}}\right.$ edição: 1898-1904).

GÖLLNER, Marie Louise (Comp.). Code International de Catalogage de la Musique. Frankfurt: C.F. Peters / IAML, 1975. 56 p. (Régles de catalogage des manuscripts musicaux, v. 4).

GONÇALVES, José Reginaldo Santos Gonçalves. A retórica da perda: os discursos do patrimônio cultural no Brasil. Rio de Janeiro: Editora da UFRJ / Iphan, 2002. 148 p.

KÖCHEL, Ludwig Richter von. Chronologisch-thematisches Verzeichniss sämmtlicher Tonwerke W. A. Mozart's. Leipzig: Breitkopf \& Härtel, 1862. xviii, 551 p.

KUHN, Thomas. A Estrutura das revoluções cientificas. 4 ed. São Paulo: Perspectiva, 1996. 257 p. (Debates, v. 115).

LANGE, Francisco Curt. La musica en Minas Gerais: un informe preliminar. Boletín Latinoamericano de Música, Rio de Janeiro, v. 6, n. 6, p. 408-494, abr. 1946.

RÉPERTOIRE INTERNATIONAL DES SOURCES MUSICALES. Normas internacionales para la catalogación de fuentes musicales históricas (Serie A/II, Manuscritos musicales, 1600-1800). Traducción española y comentarios realizados por: José V. González Valle, Antonio Ezquerro, Nieves Iglesias, C. José Gosálvez, Joana Crespí. Madri: Arco/Libros, 1996. 189 p.

SANTOS, Boaventura de Souza. Um discurso sobre as ciências. 8 ed. Porto: Afrontamento, 1996. 58 p.

SCHELLENBERG, Theodore R. Arquivos modernos: princípios e técnicas. 2. ed. Rio de Janeiro: Fundação Getúlio Vargas, 1974. 345 p.

WERSIG, Gernot. Information Science: the study of post-modern knowledge usage. Information processing and Management, v. 29, n. 2, p. 229-239, 1993. 



\title{
Perspectivas de integração do patrimônio musical brasileiro
}

\author{
André Guerra Cotta
}

\section{Introdução}

Como vimos na palestra anterior, a utilização da metodologia arquivística é um fenômeno bastante recente, sobretudo no Brasil. A própria normativa internacional foi publicada há pouco tempo atrás pelo Conselho Nacional de Arquivos. Devido ao caráter incipiente desta metodologia, não são poucas as dificuldades no que diz respeito à sua aplicação prática, inclusive a sua utilização nos sistemas de recuperação de informação estabelecidos. A proposta de uma arquivologia musical é tão mais recente e específica que não se pode esperar que a sua aplicação seja rapidamente assimilada pelas novas iniciativas de tratamento técnico de acervos musicais, sobretudo porque as suas bases teóricas precisam ser discutidas e estabelecidas coletivamente, em uma perspectiva científica transdisciplinar.

Alguns registros remotos de iniciativas de tratamento de documentação musical no Brasil - ou seja, identificação, avaliação, organização e algum tipo de descrição de documentos relacionados ao fazer musical, dentre os quais destacam-se as partes vocais ou instrumentais manuscritas - situam-se ainda no século dezenove, quando, por razões diversas, mas sem relações com a pesquisa musicológica ou histórica, empreenderam-se tais atividades. Podemos chamar esse período de fase "pré-científica", na medida em que tais empreendimentos consistiam basicamente na descrição funcional de arquivos, sem nenhuma conexão com finalidades musicológicas. Em certos casos, resultaram de processos jurídicos, como é o caso do inventário de músicas realizado por ocasião de um libelo cível em Vila Rica, em 1820 (REZENDE, 1989, p. 513); em outros, foram produzidos por razões administrativas, como é o caso do "Catálogo das músicas arquivadas na Capela Imperial", produzi- 
do por Joaquim José Maciel, em 1887, e refeito pelo seu sucessor Miguel Pedro Vasco, em 1902 (MATTOS, 1970, p. 58-59). Naquela altura, enquanto na Europa já ocorriam iniciativas de catalogação como as de Köchel e Eitner, que mencionamos na nossa palestra anterior, no Brasil oitocentista (e mesmo nas primeiras décadas do século XX) o trabalho documental de caráter musicológico era, ao que parece, praticamente inexistente. A própria historiografia musical era, de maneira geral, restrita às narrativas idealizadas, historicizantes, baseadas, quando muito, em pesquisa de campo limitada, e geralmente caracterizada pela total ausência de referência às fontes.

A essa primeira fase, seguiu-se uma outra a que podemos denominar de fase empírica, cujo início podemos situar na década de quarenta do século XX, marcada pela valorização, por parte da historiografia musical, das fontes documentais, à maneira positivista. Com base na teoria das fontes histórico-musicais do século XIX, a historiografia musical voltou-se para os conjuntos documentais produzidos no Brasil - marcadamente para a produção setecentista - sobre os quais construiu uma narrativa marcada pela busca da autenticidade, pela valorização do elemento colonial e que, de forma inesperada, deu margem ao movimento a que denominamos colecionismo preservacionista. Foi uma importante mudança de paradigma, na medida em que o patrimônio documental antes ignorado passou a ser considerado como testemunha de uma música do passado, única possibilidade de resgatar uma história agora detectável, comprovável, recuperável. Ao mesmo tempo, a partir da quase lendária figura de Francisco Curt Lange, seguiram o seu exemplo colecionista muitos pesquisadores interessados em preservar e estudar o patrimônio musical, formando, para tanto, coleções pessoais compostas de fragmentos de arquivos de corporações musicais, de músicos ou de famílias de músicos. Fragmentos, pois, na medida em que se seleciona parte de um dado arquivo (que interessa a uma determinada linha de pesquisa) e se despreza o restante, se está quebrando laços orgânicos, separando partes de um todo que, dependendo das condições, jamais poderão ser relacionadas futuramente.

É preciso destacar que, em meio a todo este movimento, algumas instituições musicais centenárias, como a Lira Sanjoanense e a 
Orquestra Ribeiro Bastos de São João Del Rei (MG), atravessaram o século XX mantendo a integridade de seus arquivos e, talvez como resposta ao colecionismo, as primeiras iniciativas institucionais de organização e tratamento de acervos musicais ocorreriam a partir de meados do século XX. Em 1954, inaugurava-se oficialmente o Museu Carlos Gomes, em Campinas (SP), que "já embrionário desde o começo do século com o nome de Arquivo Carlos Gomes ”, continha manuscritos musicais originários da família Gomes (NOGUEIRA, 1997, [p. 11]). Cerca de uma década depois, D. Oscar de Oliveira dava início ao Museu da Música, em Mariana (MG), que reunia a documentação musical dos primórdios da Arquidiocese de Mariana, à qual somaram-se acervos originários de diversas cidades mineiras, tais como Barão de Cocais e Ouro Preto. ${ }^{1}$

Em 1970 surge o catálogo temático da obra de José Maurício Nunes Garcia, de autoria de Cleofe Person de Mattos, um dos mais importantes trabalhos já realizados no Brasil, que relaciona as obras de Nunes Garcia e os documentos em que se encontravam nos respectivos acervos, com indicações de cotas, comentários detalhados e incipit musical para todas as seções de cada obra (MATTOS, 1970). A partir de meados da década de setenta, a Pontifícia Universidade Católica do Rio de Janeiro, com o apoio da Xerox do Brasil, empreendeu o projeto $O$ Ciclo do Ouro - O tempo e a música do barroco católico, que consistiu na microfilmagem de manuscritos musicais de onze acervos históricos de Minas Gerais, selecionados pela sua antiguidade ou pelo valor estético das obras neles registradas. O referido projeto resultou em um catálogo de microfilmes, que ainda hoje consiste em uma das referências em termos de catálogos de fontes para a pesquisa musicológica no Brasil (BARBOSA, 1979). O catálogo consiste em registros de obras dos séculos XVIII e XIX, com a referência ao microfilme e fotogramas, com notas da Comissão de Análise de Documentos, descrição das seções e incipit mu-

\footnotetext{
${ }^{1}$ Embora existam notícias da criação do Museu da Música já em meados da década de sessenta, segundo Resende (1989, p. 721) a instituição foi oficializada em julho de 1973. A hoje denominada Coleção Dom Oscar, a principal seção do Museu da Música, abriga acervos oriundos de cerca de trinta cidades que no século XVIII pertenceram ao Bispado de Mariana.
} 
sical da primeira seção. É curioso que os dois catálogos publicados na década de setenta não pretendam descrever um determinado acervo, mas documentos de origens diversas, selecionados através de um determinado critério musicológico. Nesta altura, já era público e notório o processo contra Curt Lange pela expatriação de patrimônio cultural, junto ao Conselho Federal de Cultura (MASSARANI, 1968), assim como havia uma corrente de defensores de Lange, como mostram as duas edições do Suplemento Literário, organizadas por Rui Mourão (MINAS GERAIS, 1973). Em 1983, depois de anos de muita polêmica, retornou ao Brasil a Coleção Curt Lange, passando então à custódia do Museu da Inconfidência de Ouro Preto (MG), onde recebeu um tratamento técnico e conta hoje com três catálogos publicados, curiosamente divididos em v.1 - Compositores Mineiros (DUPRAT, 1991), v.2 - Compositores Não-mineiros (1994) e v.3 Compositores Anônimos (2002). Entre os dois últimos volumes, surge o Catálogo do acervo do Museu Carlos Gomes (NOGUEIRA, 1997) e a Seção de Música do Arquivo da Cúria Metropolitana de São Paulo recebe uma primeira descrição, embora já fosse há muito tempo citada em trabalhos musicológicos (CASTAGNA, 1999). Nesse mesmo período, vem para a Universidade Federal de Minas Gerais o arquivo pessoal de Francisco Curt Lange, que pouco depois já conta com um inventário (TUGNY, 2002). Como se pode ver, as iniciativas institucionais de tratamento de acervos musicais ocorrem em número cada vez maior nas últimas décadas do século vinte, contribuindo significativamente para o conhecimento do patrimônio musical brasileiro.

\section{Patrimônio Cultural}

Como já mencionamos, a noção tradicional de patrimônio cultural está ligada ao conceito de patrimônio material e tem sido adotada de forma excludente, o que se reflete inclusive na falta de políticas públicas para preservação dos acervos de música, geralmente relegados a um limbo entre o patrimônio documental e o patrimônio cultural, muito específicos para as instituições que tratam da documentação tradicional (como os arquivos públicos) e igualmente específicos para as instituições voltadas para a preservação do 
patrimônio cultural visto por aquela ótica (como os museus e o próprio IPHAN).

A este aspecto da questão soma-se o novo conceito de patrimônio imaterial, que amplia o conceito de patrimônio cultural, incluindo nele práticas culturais, inclusive musicais. Mas o fato é que mais recentemente as políticas públicas vem sendo mais sensíveis à necessidade de inclusão do patrimônio documental relacionado à música, de maneira que é notável o crescimento de iniciativas de tratamento de acervos musicais no Brasil, tais como as de Viçosa, Minas Gerais (FONSECA, 2004, p. 280), o Arquivo Histórico Monsenhor Horta, também em Minas (LIMA, 2003, p. 171) e o próprio projeto Patrimônio Musical na Bahia, que tem revelado uma extensão e um conteúdo não inesperados, mas impressionantes pela extensão e pela quantidade (SOTUYO BLANCO, 2004).

Contudo, talvez estejamos ainda vivendo a "fase empírica" a que nos referimos acima, pois as iniciativas de intervenção nos acervos ocorrem ainda de maneira isolada, muitas vezes sem a mesma orientação técnica, e porque, apesar das tentativas de estabelecer parâmetros técnicos para o tratamento de acervos musicais, trabalhamos sobre um edifício teórico ainda em construção, inclusive no que diz respeito à terminologia. A própria distinção entre arquivo e coleção, a que já nos referimos, é pouquíssimo conhecida, o que leva a um freqüente uso interconceitual. ${ }^{2}$ A utilização, em português, de um termo como acervo, tem sido cada vez mais comum, pelo fato de que se trata de um termo neutro, podendo designar tanto arquivos como coleções. Mas o fato de ser ele neutro pode ser, por si só, problemático, na medida em que contribui para a confusão interconceitual, pois não faz com que esta terminologia seja observada e difundida, o que, em nossa opinião, é fundamental para que as futuras iniciativas de tratamento técnico de acervos de música não incorram nos mesmos erros e preconceitos do passado. Pois o problema não se resume à confusão terminológica, pois é a própria

\footnotetext{
${ }^{2}$ Isso sem mencionar o problema de sua tradução para outras línguas, em que seus equivalentes podem ter usos interconceituais que dificultam a sua compreensão ou se apóiam em uma tradição cultural que vai contra tal conceituação, como é o caso do termo inglês collection.
} 
metodologia de tratamento de acervos que está em questão. A observação do princípio de proveniência, mais adequada no caso de conjuntos arquivísticos, em geral é negligenciada pelo simples desconhecimento.

Existem também outras dificuldades que envolvem o tratamento técnico de acervos musicais, sejam eles arquivos e coleções: o fato de serem públicos ou privados. A primeira das dificuldades, no caso de acervos privados, é a questão do acesso. Muitas vezes, por necessidade de proteção ou mesmo por uma questão de respeito reverencial, o acesso a certos acervos privados é simplesmente negado, transformando-os em tesouros intocáveis - o que na maioria dos casos significa também relegá-los ao esquecimento, muitas vezes em péssimas condições de conservação, que fatalmente os levarão ao desaparecimento em questão de décadas. Porém, o fato é que, uma vez inacessíveis, ainda que bem conservados, tais documentos não têm sentido, pois não tem valor por si só, em si mesmos, mas somente na medida em que são interpretados, executados, estudados. Por outro lado, temos situações em que, mesmo depois de considerado como tesouro intocável por gerações, o acervo é tratado como lixo por outra, muitas vezes destinado ao fogo em via pública, como testemunhou Curt Lange ainda em meados do século vinte (LANGE, 1946, p. 482).

O problema do acesso é um dos sérios entraves para a pesquisa e para a preservação do patrimônio cultural brasileiro, problema que, em tese, não deve existir nos acervos públicos, legalmente considerados como de livre acesso (exceto nos casos de sigilo previstos em lei, o que não seria o caso de documentos musicais). O problema dos acervos públicos é geralmente, o da falta de recursos, tanto de ordem material como humana. Belloto (1990) considera ainda uma terceira categoria, a dos arquivos sociais, como os arquivos eclesiásticos, que, embora privados, são de interesse público - nestes, podese encontrar mesmos problemas apontados acima, embora sejam, pelo seu próprio caráter, potencialmente mais abertos à comunidade e a iniciativas de tratamento técnico. 


\section{Integração e recuperação da informação}

O sucesso de tais iniciativas, entretanto, depende cada vez mais da capacidade de integrá-las, com vistas a uma padronização de parâmetros teóricos e técnicos para a sua identificação, organização e descrição, sobretudo porque isso tem conseqüências diretas no que diz respeito à recuperação da informação.

A primeira grande iniciativa de padronização de formatos de descrição surgiu no campo da Biblioteconomia, com o International Standard for Bibliographic Description - ISBD, iniciado na década de 1940 e publicado em 1969, que mais tarde deu elementos para a criação de formatos de intercâmbio de informação em meios eletrônicos e digitais, entre os quais destaca-se o MARC-Machine-Readable Cataloging. Apenas mais recentemente, já no apagar das luzes do século, surgiu a primeira iniciativa de padronização de descrição de material arquivístico, o International Standard for Archival Description (general) - ISAD $(\mathrm{G})$, publicado pelo Conselho Internacional de Arquivos em 1994, em Estocolmo (Suécia). ${ }^{3}$

Especificamente no campo da música, a primeira iniciativa consistiu na publicação, pela Associação Internacional de Bibliotecas Musicais, das Rules for Cataloguing Music Manuscripts (GÖLLNER, 1975), de orientação claramente bibliográfica e voltada basicamente para a confecção de fichas catalográficas. A necessidade de integração dos dados relativos às fontes manuscritas de música já estava presente nos congressos realizados pela Sociedade Internacional de Musicologia desde o início do século passado e levaram ao surgimento do Répertoire Internationale de Sources Musicales RISM, um projeto importante não somente pelo seu âmbito mundial, mas pela sua importância histórica, pois vem sendo continuamente adaptado ao avanço das tecnologias de informação, passando dos catálogos impressos dos anos 1950 aos meios digitais dos anos 1990, como o CD-ROM e a World Wide Web. Mas foi somente em 1996 que o grupo de trabalho RISM-Espanha publicou as Normas internacionales para la catalogación de fuentes musicales históri-

\footnotetext{
${ }^{3}$ A ISAD $(G)$ teve sua primeira versão brasileira em 1998 e uma segunda edição, revisada e ampliada, em 2000, ambas realizadas pelo Arquivo Nacional do Brasil, no Rio de Janeiro (CONSELHO INTERNACIONAL DE ARQUIVOS, 2000).
} 
cas (Serie A/II, Manuscritos musicales, 1600-1800), versão espanhola das normas do projeto RISM, publicação que representou uma contribuição significativa rumo à padronização de normas para a descrição de fontes musicais. O fato de que o RISM tenha se adaptado às tecnologias digitais é extremamente importante, pois a própria noção de recuperação da informação modificou-se profundamente com a evolução dos meios digitais, ao ponto de se criar um fórum específico para a discussão da recuperação da informação musical (mundialmente conhecida pela sigla MIR, de Music Information Retrieval) o International Symposium on Music Information Retrieval - ISMIR, que já conta com quatro edições, entre 2000 e 2004.

Os instrumentos de busca tradicionais, tais como os guias, inventários, catálogos e repertórios, ${ }^{4}$ ainda que basicamente pensados para publicação em papel, podem ter versões em meio digital. Porém, os recursos de instrumentos de busca baseados em tecnologias digitais são muito diferentes, pela sua própria natureza: bases de dados, redes de informação, listas de discussão ou até mesmo newsletters são dotados de uma lógica menos linear, mais dinâmica e flexível que os meios impressos ou as fichas catalográficas, para os quais muitas das normativas foram pensadas. Neste sentido, as normas do RISM têm vantagens pelo fato de terem sido pensadas para a descrição em bases de dados, para o estudo exaustivo das fontes musicais em 94 campos descritivos e ainda a vantagem adicional de possuir termos e abreviaturas padronizados internacionalmente, utilizados por cerca de 30 países.

Por outro lado, o caráter centralizante do sistema RISM é um sério problema, sobretudo em termos políticos e econômicos. ${ }^{5}$ Por um lado, o software Pflege und Information kategorisierter

\footnotetext{
${ }^{4}$ Sem entrar detalhes sobre os instrumentos tradicionais, podemos dizer que eles podem destinar a descrever desde o nível mais geral - o arquivo, como é o caso dos guias - até os níveis mais específicos, como séries, dossiês e até mesmo um único item documental - como é o caso da edição de fontes. Para mais informações sugerimos a leitura de Belloto (1991, p. 108-140) e Cotta (2000, p. 93-99).

${ }^{5}$ Recentemente, no VI Encontro de Musicologia Histórica, em Juiz de Fora, apresentamos reflexões sobre as vantagens e desvantagens da utilização do RISM no caso do Brasil, algumas delas apontamos aqui, se entrar em detalhes.
} 
Dokumente - PIkaDo, foi criado especificamente para a descrição e o cruzamento de dados de fontes musicais, permitindo até mesmo a busca por incipits melódicos. Por outro lado é um formato proprietário, consideravelmente caro e apresenta limitações para intercâmbio de dados. Apesar de que haja um projeto de conversibilidade de seus registros para outros formatos de intercâmbio de informação bibliográfica, Keil reporta que:

O formato PIkaDo é utilizado pela base de dados do RISM e por um pouco mais da metade dos 30 países que colaboram com o projeto. Como este formato não é compatível com os formatos mais freqüentemente utilizados pelas bibliotecas (UNIMARC e MARC 21) e não permite a troca de dados, o secretariado central do RISM optou por uma mudança de formato. Em colaboração com a Staatsbibliothek de Berlim, decidiu-se desenvolver um programa em formato MAB (formato alemão recentemente concluído) que comporta uma interface de importação/ exportação para os dois outros grandes formatos, UNIMARC e MARC 21. Este programa permitirá aos diferentes grupos nacionais alimentar regularmente a base de dados do RISM A/II, mesmo que os dados estejam originalmente em UNIMARC ou em MARC 21. Os grupos de trabalho nacionais deverão adquirir uma licença mediante $1000 \cdot$, e então 150 • por ano. Entretanto, este projeto não está ainda validado e os testes de conversão, notadamente, estão ainda em curso para estudar a sua perfeita exeqüibilidade. (KEIL, 2003, tradução nossa) ${ }^{6}$

\footnotetext{
${ }^{6}$ No original: "Le format PIkaDo est utilisé pour la base de donnée du RISM et par un peu plus de la moitié des 30 pays qui collaborent au projet. Ce format n'étant pas compatible avec les formats les plus fréquemment utilisés par les bibliothèques (Unimarc et Marc 21) et ne permettant pas les échanges de données, le secrétariat central du RISM a opté pour un changement de format. En collaboration avec la Staatsbibliothek de Berlin, il a été décidé de développer un programme en format $M A B$ (format allemand récemment mis au point) comportant une interface import) export vers les deux autres grands formats, Unimarc et Marc 21. Ce programme permettra aux différents groupes nationaux d'alimenter régulièrement la base de données du RISM A/II, que les données soient à l'origine en Unimarc ou en Marc 21. Les groupes de travail nationaux devront acquérir une licence moyennant 1000 -, puis 150 •; par an. Néanmoins, ce projet n'est pas encore validé et des tests de conversion, notamment, sont encore en cours pour en étudier la parfaite faisabilité".
} 
Existem ainda dois aspectos cruciais. As normas não orientam quanto à metodologia de tratamento (como por exemplo, observar a distinção entre coleções e arquivos), apenas quanto à descrição. E finalmente há o problema do custo pelo acesso, que se tornou o grande problema do RISM, na medida em que desde julho de 2002 a base de dados do RISM na World Wide Web, anteriormente de acesso gratuito e universal, passou a exigir assinatura anual (via NISC), impraticável para pesquisadores dos países do terceiro mundo. ${ }^{7}$ Estes problemas levam a pensar que a adoção do sistema RISM talvez não seja a melhor solução para a integração das iniciativas de tratamento de acervos musicais no Brasil.

O musicólogo José Maria Neves apresentou, em um artigo intitulado Arquivos de manuscritos musicais brasileiros: breve panorama (NEVES, 1998, p. 140), um histórico detalhado de iniciativas para a padronização de elementos descritivos para fontes musicais, mencionando o projeto, que não chegou a se concretizar, de uma Rede Nacional de Arquivos Musicais, pensada para suprir a falta de instrumentos de busca para os diversos acervos musicais brasileiros. Neves discutiu (ainda que não na versão escrita de seu trabalho) a diferença entre a noção de sistema, que é geralmente centralizadora, e a de rede, que é, ao contrário, descentralizada, observando que:

a intercomplementaridade de nossos arquivos musicais somente produzirá seus resultados quando pudermos lançar mão de catálogos sistemáticos que incluam todas as informações disponíveis [...] e que, por sua construção, permitam todos os cruzamentos desejáveis. Por isto mesmo, o trabalho de cada musicólogo fica ainda mais relacionado com o dos demais, estabelecendo-se [uma] rede que potencializa os esforços (NEVES, 1998, p. 145).

A Web é uma possibilidade concreta para um trabalho em rede, integrado, cooperativo e descentralizado, ao contrário do RISM, que se baseia em uma estrutura centralizada. Considerando o que Pierre Lévy (1993, p. 25) chamou de Princípio de multiplicidade e de encaixe das escalas ou, mais ainda, o Princípio de mobilidade dos centros,

${ }^{7}$ Cf. $<$ http://www.nisc.com $>$. 
a própria lógica da Web favorece o trabalho em rede, pois "a rede não tem centro, ou melhor, possui permanentemente diversos centros [...] perpetuamente móveis, saltando de um nó a outro, trazendo ao redor de si uma ramificação infinita" (LÉVY, 1993, p. 26).

De fato a utilização da Web para a integração de iniciativas de descrição de acervos de fontes para a pesquisa musicológica é uma perspectiva que vem se tornando cada vez mais atraente, mas ainda há muitos obstáculos a vencer neste sentido. Já há alguns anos Barry S. Brook, em seu trabalho panorâmico sobre os catálogos temáticos de música, observava que "utilizando um navegador Web com as palavras-chave 'thematic catalogue in music' recupera-se mais de 100.000 registros, a maior parte dos quais não diz respeito à música " (BROOK; VIANO, 1997, p. xvii, tradução nossa). ${ }^{8}$ Eis um exemplo cabal de como a WWW tornou-se uma babel informacional, pois ao mesmo tempo em que disponibiliza milhões de páginas, cria um sério problema em termos de recuperação da informação. Apesar disso, a World Wide Web, pelos recursos informacionais que disponibiliza, é um meio altamente promissor, sobretudo pelas novas tecnologias ligadas à Hyper Text Mark-up Language - HTML. Uma das mais promissoras, no que diz respeito à recuperação da informação, é a chamada eXtended Markup Language - XML, uma linguagem de metadados que está revolucionando a $W e b$, com perspectivas positivas para o enfrentamento dos problemas de intercâmbio de informação, inclusive na recuperação de informação musical (DOWNIE, 2003, p. 323-324).

Perry Roland observa que sistemas de metadados como o MARC e a $\mathrm{EAD}^{9}$ são inadequados para a recuperação de informação musical e destaca a grande flexibilidade e autonomia que a XML pode oferecer, na medida em que é uma meta-linguagem - uma linguagem que descreve linguagens - cuja aplicação permite a definição e interação de linguagens específicas, independente de plataformas e softwares:

\footnotetext{
${ }^{8}$ No original: "Utilizing a Web browser under the keywords 'thematic catalogue in music' calls up over 100.000 entries, most of which do not pertain to music.".

${ }^{9}$ Encoded Archival Description, uma linguagem baseada na $\operatorname{ISAD}(\mathrm{G})$, utilizando XML.
} 
A principal razão para usar XML é que ela é um padrão aberto, independente de plataformas. A XML é um subconjunto simplificado do padrão SGML - Standard Generalized Markup Language (ISO8879). Apesar do seu nome, a XML não é propriamente uma linguagem de marcação, mas uma meta-linguagem, desenhada para suportar a definição de linguagens específicas (community-specific). Por não haver limites para o uso de elementos através de múltiplos 'namespaces' ou na profundidade estrutural que uma linguagem de marcação pode empregar, a XML é muito poderosa. Além disso, é fácil de implementar. Os desenvolvedores não precisam criar suas próprias ferramentas de criação (authoring), leitura (parsing), transformação (transforming) ou exibição (displaying) de XML. Existente um já crescente conjunto de ferramentas gratuitas disponíveis (ROLAND, 2000, tradução nossa). ${ }^{10}$

Finalmente, cabe a observação de que a XML, além de ser "Human-readable”, légível para nós, pode permitir uma interação entre as diferentes linguagens que ela própria estrutura, de modo que seria possível integrar a Encoded Archival Description (EAD) - que se aplica à descrição arquivística - com alguma das várias iniciativas de Marcação em XML voltadas para a música, como SMDL - Standard Music Description Language, MusicXML Definition, Music Markup Language (MML), MusiXML e Musical Notation Markup Language (MNML). Nessa perspectiva, a utilização de novas linguagens de marcação, especialmente da XML, revela-se como uma possibilidade tecnológica de integração das diversas iniciativas de tratamento e descrição de fontes para a pesquisa musicológica no Brasil.

\footnotetext{
${ }^{10}$ No original: "The foremost reason for using XML is that it is a platformindependent, open standard. XML is a simplified subset of the Standard Generalized Markup Language (ISO8879) standard. Despite its name, XML isn't really a markup language, but a meta-language, designed to support the definition of communityspecific languages. Because there are no limits on the use of elements across multiple namespaces or on the structural depth that a markup language might employ, XML is very powerful. Furthermore, it is easy to implement. Developers need not create their own tools for authoring, parsing, transforming or displaying XML. There is already an ever-growing set of free tools available".
} 


\section{Conclusões em perspectiva}

É urgente uma definição de uma política coletiva para o tratamento de acervos musicais no Brasil, sobretudo no que diz respeito às metodologias. Alguns aspectos como a ética na relação arquivista/pesquisador/comunidade e nas diretrizes para reprodução e utilização de fontes são fundamentais, assim como a definição de parâmetros para digitalização de documentos. ${ }^{11}$

A criação de estratégias para a autogestão de acervos musicais, sejam eles públicos, privados ou sociais, também é importante, pois não se pode contar eternamente com as agências de fomento e os programas de incentivo fiscal. Por outro lado, a majoração de preços para a reprodução de documentos pode significar um sério entrave para a pesquisa. Todas estas questões merecem um amplo debate, talvez nos futuros encontros de área, mas também - por que não? - nas listas de discussão existentes, como a lista da ANPPOM e a Lista - Acervos Musicais Brasileiros (L-AMB). ${ }^{12}$

Mas, finalmente, a questão crucial para o futuro da integração do patrimônio musical braileiro é, de nosso ponto vista, justamente a definição de parâmetros técnicos para o intercâmbio e a recupera-

\footnotetext{
${ }^{11}$ Por ocasião do Ciclo de Palestras tomei conhecimento do projeto "Banco de Partituras" da ONG conhecida como Casa das Filarmônicas, sediada em Salvador, mas realizado junto a filarmônicas de diversas cidades da Bahia, cujo funcionamento pareceu-me extremamente prejudicial do ponto de vista da preservação do patrimônio musical, na medida em que, segundo me foi explicado, sem observar o principio de respeito aos fundos, o projeto substitui as partes manuscritas antigas por partes editadas em microcomputador, impressas em jato-de-tinta sobre papel comum. Pior: não se sabe ao certo qual é o destino das partes antigas que, ao que parece, não retornam ao arquivo da instituição de onde provêm. Ora, o simples fato de retirar documentos do conjunto orgânico a que historicamente pertencem é um absurdo, como procuramos mostrar, na medida em que isto significa fragmentar os arquivos. Mas este erro é ainda agravado pelo fato de que, ao que tudo indica, o referido projeto utiliza a tecnologia digital como um fator de desagregação, pois não favorece as comunidades das filarmônicas com o domínio desta tecnologia, apenas oferecendo-lhes um produto frágil, gerando uma relação de dependência eticamente criticável.

${ }^{12} \mathrm{~A}$ L-AMB é uma lista aberta à comunidade, bastando, para inscrever-se, mandar uma mensagem para $<1$ amb-subscribe@yahoogroups.com $>$. A lista da ANPPOM é apenas para os seus associados.
} 
ção de informação musical, com vistas ao estabelecimento gradativo de uma rede nacional cooperativa, para o que procuramos aqui colaborar.

(Palestra ministrada em 17 de Agosto de 2004) 


\section{Referências Bibliográficas}

ARAÚJO, V.M.R.H. de. Sistemas de recuperação da informação SRIs. In: Sistemas de recuperação da informação. Rio de Janeiro: 1994. Capítulo 5, p. 84-121.

BELLOTTO, Heloísa Liberalli. Arquivos permanentes: tratamento documental. São Paulo: T.A. Queiroz, 1991. 198 p.

BROOK, Barry S.; VIANO, Richard. Thematic catalogues in music: an annotated bibliography. 2nd. ed. Stuyvesant: Pendragon, 1997. L, 602 p.

BUSH, Vannevar. As we may think. The Atlantic Monthly, july, 1945. Disponível em: <http://www.ps.uni-sb.de/ duchier/pub/vbush/ vbush-all.shtml>. Acesso em: 10 out. 2004.

CASTAGNA, Paulo. A organização e catalogação da Seção de Música do Arquivo da Cúria Metropolitana de São Paulo. In: ENCONTRO NACIONAL DA ANPPOM, 11., 1998, Campinas. Anais... Campinas: UNICAMP / Instituto de Artes, 1999. p. 231-237.

CONSELHO NACIONAL DE ARQUIVOS. ISAD $(G)$ : Norma Geral Internacional de Descrição Arquivística. 2. ed. Rio de Janeiro: Arquivo Nacional, 2001. 110 p. Disponível em: <http:// www.arquivonacional.gov.br/>. Acesso em: 23 out. 2004.

COTTA, André Guerra. O tratamento da informação em acervos de manuscritos musicais brasileiros. 2000. 291 folhas. Dissertação (Mestrado em Ciência da Informação). Escola de Biblioteconomia, Universidade Federal de Minas Gerais, Belo Horizonte, 2000.

DOWNIE, J. Stephen. Music information retrieval. In: Annual Review of Information Science and Technology 37, Ed. Blaise Cronin, p. 295-340. Medford, New Jersey: Information Today, 2003. Disponível em: $<$ http://music-ir.org/downie_mir_arist37.pdf $>$. Acesso em: 18 out. 2004 
DUPRAT, Régis; BALTAZAR, Carlos Alberto. (Coord.). Museu da Inconfidencia. Acervo de manuscritos musicais: Coleção Francisco Curt Lange, v. 1: compositores mineiros dos séculos XVIII e XIX. Belo Horizonte: UFMG, 1991. 174 p.

DUPRAT, Régis; BALTAZAR, Carlos Alberto. (Coord.). Museu da Inconfidência. Acervo de manuscritos musicais: Coleção Francisco Curt Lange, v.2: compositores não-mineiros dos séculos XVI a XIX. Belo Horizonte: UFMG, 1994. 92 p.

DUPRAT, Régis; BIASON, Mary Angela. (Coord.). Museu da Inconfidência. Acervo de manuscritos musicais: Coleção Francisco Curt Lange, v.3: compositores anônimos. Belo Horizonte: UFMG, 2002. 239 p.

FONSECA, Modesto Flávio Chagas. Acervo de manuscritos de Viçosa (MG). In: ENCONTRO DE MUSICOLOGIA HISTÓRICA, 5., 2002, Juiz de Fora. Anais... Juiz de Fora: Centro Cultural PróMúsica, 2004. p. 280-282.

GÖLlnER, Marie Louise (Comp.). Code International de Catalogage de la Musique. Frankfurt: C.F. Peters / IAML, 1975. 56 p. (Régles de catalogage des manuscripts musicaux, v. 4).

KEIL, Klaus. Le RISM dans les pays d'Europe de l'Est (Rapport du secrétariat central du RISM). In: CONGRESSO DAASSOCIAÇÃO INTERNACIONAL DE BIBLIOTECAS MUSICAIS, 2003, Tallinn, Estônia. Estônia, 2003. Disponível em: $<\mathrm{http}$ ://www.aibm-france.org/ congres_internationaux/tallinn_2003/ci03_compte-rendu_8.htm $>$. Acesso em: 27 out. 2004.

KERMAN, Joseph. Musicologia. São Paulo: Martins Fontes, 1987. $331 \mathrm{p}$.

LANGE, Francisco Curt. La musica en Minas Gerais: un informe preliminar. Boletín Latinoamericano de Música, Rio de Janeiro, v. 6, n. 6, p. 408-494, abr. 1946. 
LEVY, Pierre. As tecnologias da inteligência. O futuro do pensamento na era da informática. Rio de Janeiro: Editora 34, 1993. 208 p.

LIMA, José Arnaldo Coelho de Aguiar. Arquivo Histórico Monsenhor Horta: estilhaços. In: COLÓQUIO BRASILEIRO DE ARQUIVOLOGIA E EDIÇÃO MUSICAL, 1., 2003, Mariana. Anais... Mariana: Fundação Cultural e Educacional da Arquidiocese de Mariana, 2004. p. 171-192.

MASSARANI, Renzo. O descobrimento das partituras que desapareceram. Fatos e fotos. Rio de Janeiro, n. 392, 8 ago. 1968.

MATTOS, Cleofe Person de. Catálogo Temático. José Maurício Nunes Garcia. Brasília: MEC; Rio de Janeiro: Gráfica Olímpica Editora, 1970. 413 p.

MINAS GERAIS. Diário Oficial de Minas Gerais. Curt Lange - O descobridor - I. Minas Gerais, Suplemento Literário (org. Rui Mourão). Belo Horizonte, Imprensa Oficial, n 355, ano VIII, 16 jun. 1973, 12 p.

MINAS GERAIS. Diário Oficial de Minas Gerais. Curt Lange - O descobridor - II. Minas Gerais, Suplemento Literário (org. Rui Mourão). Belo Horizonte, Imprensa Oficial, n 356, ano VIII, 23 jun. 1973, 12 p.

NEVES, José Maria. Arquivos de manuscritos musicais brasileiros: breve panorama. In: SIMPÓSIO LATINO-AMERICANO DE MUSICOLOGIA, 1., 1997, Curitiba. Anais... Curitiba: Fundação Cultural de Curitiba, 1998. p.137-163.

NOGUEIRA, Lenita Waldige Mendes. Museu Carlos Gomes: catálogo de manuscritos musicais. São Paulo: Arte e Ciência, 1997. $415 \mathrm{p}$.

RÉPERTOIRE INTERNATIONAL DES SOURCES MUSICALES. Normas internacionales para la catalogación de 
fuentes musicales históricas (Serie A/II, Manoscritos musicales, 1600-1800). Traducción española y comentarios realizados por: José V. González Valle, Antonio Ezquerro, Nieves Iglesias, C. José Gosálvez, Joana Crespí. Madri: Arco/Libros, 1996. 189 p.

REZENDE, Maria da Conceição. A música na história de Minas colonial. Belo horizonte: Itatiaia; Brasília: INL, 1989.765 p.

ROLAND, Perry. XML4MIR: Extensible Markup Language for Music Information Retrieval. SMIR, 2000. Disponível em: $<$ http:// ciir.cs.umass.edu/music2000/papers/roland_paper.pdf $>$. Acesso em: 20 out. 2004.

SOTUYO BLANCO, Pablo. Arquivos de Música na Bahia. In: COLÓQUIO BRASILEIRO DE ARQUIVOLOGIA E EDIÇÃO MUSICAL, 1., 2003, Mariana. Anais... Mariana: Fundação Cultural e Educacional da Arquidiocese de Mariana, 2004. p. 249-269.

TUGNY, Rosângela Pereira de. O inventário do Acervo Curt Lange da UFMG: contribuições para uma ética da pesquisa de campo em musicologia. In: ENCONTRO DE MUSICOLOGIA HISTÓRICA, 4., Juiz de Fora, 2000. Anais... Juiz de Fora: Centro Cultural PróMúsica; Rio de Janeiro: Fundação Biblioteca Nacional, 2002 . p. 262276. 


\title{
O Patrimônio Musical na Bahia: Diagnóstico, Estratégias e Propostas
}

\author{
Pablo Sotuyo Blanco
}

\section{Apresentação}

Não acreditando que a tradição musical na Bahia comece apenas no primeiro século da colonização americana (segundo foi afirmado no passado), mas vinda de tempos mais remotos, no que diz respeito à tradição musical européia, o ano de 1500 pode ser tomado como limite cronológico às buscas musicológicas relativas ao nosso passado musical escrito e à documentação contextual correspondente.

Os arquivos baianos têm sido fonte de múltiplas pesquisas por parte de muitos pesquisadores já faz muito tempo. Mas a musicologia na Bahia demorou muito tempo a se consolidar como área acadêmica de pesquisa e a tal riqueza documental foi poucas vezes reconhecida ou dignificada. No ano de 1976, Bruno Kiefer declarava:

As pesquisas do passado musical baiano são muito escassas. As razões devem ser várias. Entre elas figura, sem dúvida alguma, a pouca importância que deve ter e ainda tem a música erudita na cultura brasileira. Não há necessidade de muita pesquisa para se constatar a grande ignorância que reina, mesmo nas camadas cultas, em relação à chamada música erudita brasileira. [...] Tal situação deve prejudicar o interesse por nosso passado musical e dificultar a concessão dos auxílios indispensáveis. Em todo caso, a julgar pelas descobertas feitas em vários Estados, pode-se alimentar a esperança de futuros achados, talvez valiosos. (KIEFER, 1976, p. 18).

Na intenção de concretizar tais anseios musicológicos, o Programa de Pós-Graduação em Música da Universidade Federal da Bahia iniciou, em maio de 2003, o projeto "O Patrimônio Musical na 
Bahia" com apoio da CAPES. Este projeto institucional visa a consolidação da pesquisa musicológica na UFBA e no Estado, através de uma série de ações (levantamento, catalogação, estudo analítico e divulgação de fontes documentais musicais e bibliográficas constantes na Bahia) e eventos (palestras, conferências, congressos, encontros, concertos e comemorações diversas) que serão realizadas no período 2003-2007, duração máxima prevista do projeto.

\section{Antecedentes}

Várias foram as consequiências do deslocamento da capital da colônia portuguesa em território americano da Bahia para o Rio de Janeiro em 1763. Em termos gerais, pode-se afirmar que as mesmas ultrapassaram o âmbito político, atingindo, inclusive, o plano da consciência coletiva, com as mudanças de atitude (provincianas ou metropolitanas) dela decorrentes. Ao mesmo tempo em que dita mudança de metrópole enquanto centro cultural acontecia, o foco dos interesses culturais e dos investimentos (econômicos e/ou acadêmicos) em "cultura" também parece ter sido deslocado.

Realizando uma revisão bibliográfica preliminar, pode-se verificar que os arquivos baianos de música foram fonte relevante de pesquisa em música desde mais de um século. Os documentos neles depositados foram avaliados tanto por pesquisadores brasileiros quanto por estrangeiros. Entre os brasileiros se encontram baianos (como Manuel Querino, Guilherme de Mello, Sílio Boccanera Jr., Frederico Dantas, Conceição Perrone, Manuel Veiga, Ilza Nogueira, Paulo Costa Lima, Lucas Robatto e Edmundo Hora, entre tantos outros), pernambucanos (Jaime C. Diniz), paulistas (Régis Duprat e Paulo Castagna), cariocas (José Maria Neves, Adeilton Bairral) e paranaenses (Rogério Budasz), entre os mais significativos.

Mas o indispensável retorno direto dessas ações para os acervos pesquisados ou para a comunidade envolvida nem sempre aconteceu como seria de se esperar. Em alguns dos casos, a falta de retorno foi o menor dos problemas detectados.

Seguindo a inércia dos "deslocamentos" históricos, certos documentos foram também "deslocados" - em nome da melhor preservação dos originais - para serem produto de estudos e divulgação 
nem sempre satisfatórios, em eventuais melhores condições acadêmicas e/ou mercadológicas nas diversas metrópoles.

Essa "colecionismo deslocador", prática comum entre certos musicólogos históricos do Brasil e da América toda (até hoje, infelizmente), pretensamente justificada por uma suposta supremacia de capacidade e infraestrutura, aceita ou tolerada pelos baianos, deveria ser rejeitada a priori pela aculturação (no sentido de esvaziamento e de perda da memória cultural) que significa para a Bahia e, eventualmente, para o Brasil como um todo. É mister lembrar aqui deslocamentos significativos como a doação que Guilherme de Melo fez da sua coleção privada para o Rio de Janeiro; do traslado do acervo musical do Convento do Carmo de Salvador para Belo Horizonte, por decisão da própria ordem ou, em tempos mais recentes, da situação das obras de Ernst Widmer, atualmente localizadas na Suíça por vontade do próprio compositor, ou de parte da produção musical de Nikolau Kokron, retirada da Escola de Música de UFBA pela família após a morte do compositor e que atualmente não é possível localizar.

De que adiantaria produzir conhecimento e cultura na Bahia (ou no Nordeste) se eles devessem ser sistematicamente "deslocados" e "promovidos" a depósitos das metrópoles brasileiras ou estrangeiras para ganhar durabilidade ou permanência? Eis o visível prejuízo que o nosso Estado (e a nossa região como um todo) ganha a partir do preconceito de um Brasil que ainda custa em se assumir como plural e se articular na sua múltipla dimensionalidade.

O status quo de aceitação ou conivência com tais práticas metodológicas (compreendidas como resultado da influência museística e colecionista franco-germânica e/ou anglo-saxônica em relação às culturas externas) fez parte da negligência local e regional em relação aos arquivos baianos, os quais ainda se ressentem das "doações" e "vendas" de documentos locais, realizadas com particulares e/ou instituições metropolitanas.

Por outro lado, constata-se uma atitude de negação ou negligência por parte de certos pesquisadores em relação aos nossos arquivos quando, ao desenvolverem visões panorâmicas da pesquisa no Brasil, não se referem a nenhum arquivo baiano, nem fazer menção de pesquisa alguma relativa à Bahia, omitindo tanto as referên- 
cias que Jaime C. Diniz fez aos arquivos da Santa Casa da Misericórdia, da Sé Metropolitana de Salvador, e/ou do Arquivo Histórico Municipal, quanto as que eles mesmos e/ou os seus orientandos realizaram de materiais oriundos de arquivos eclesiásticos de Salvador, inclusive durante o saudoso arcebispado de Dom Lucas Moreira Neves. ${ }^{1}$ É como se, depois do "deslocamento" a lembrança das origens não importasse mais. Como se a Bahia (ou o Nordeste) não apresentasse nenhuma relevância em termos arquivísticos brasileiros, uma vez que os documentos considerados de maior importância tivessem sido recolhidos para a sua eventual salvaguarda.

\section{Sobre o projeto e a sua articulação}

Levando em consideração os antecedentes aqui apresentados e a atual situação de emergente consciência local em relação ao patrimônio histórico musical na Bahia, tanto no plano social quanto no institucional e no acadêmico, o presente projeto vem consolidar os esforços iniciados, nos últimos anos, por pesquisadores como Conceição Perrone (através do projeto de pesquisa "A música nas igrejas da Bahia"), por Manuel Veiga (através das pesquisas sobre as Modinhas e a "Impressão Musical na Bahia"), e por Ilza Nogueira (através do projeto "Marcos Históricos da Composição Contemporânea na UFBA"), sendo estes dois últimos disponibilizados na Internet.

Levando em consideração que o estabelecimento da musicologia histórica na Bahia, objetivo principal deste projeto, não poderia nunca significar nem implicar a conclusão das pesquisas relativas a dita área no Estado baiano num período de apenas quatro anos, desde o seu início procuramos estabelecer um cronograma viável através de uma série de etapas que permitissem cumprir os objetivos estabelecidos no projeto de maneira crescente, gradativa e acumulativa, mas não necessariamente conclusiva . Como surge da

\footnotetext{
${ }^{1}$ Exemplo disto aparece na participação de José Maria Neves na mesa-redonda II "Perspectivas da Pesquisa Musicológica na América Latina (séc. XVI a XX)" durante o I Simpósio Latino-americano de Musicologia (Curitiba, 1997). Cf. José Maria Neves, Arquivos de Manuscritos Musicais Brasileiros: Breve Panorama Recuperação e propostas para uma sistematização latino-americana, In: Anais I Simpósio Latino-americano de Musicologia (Curitiba: Fundação Cultural de Curitiba, 1998), p. 137-163.
} 
observação da Tabela 1, as atividades continuam ou não, dependendo das suas características inerentes e da sua articulação intrainstitucional e/ou inter-institucional.

No nível intra-institucional, além do suporte recebido pela PróReitoria de Pós-Graduação e Pesquisa (tanto pela administração das verbas envolvidas no projeto, quanto pela concessão de bolsas de Iniciação Científica aos projetos por nós encaminhados ao Programa Institucional que contempla ditas atividades, o PIBIC), é mister destacar o apoio irrestrito que a Direção da Biblioteca Central e do Sistema de Bibliotecas da UFBA tem manifestado ao nosso projeto desde o seu início. Esperamos contar no futuro com a colaboração e apoio de outras duas unidades estrategicamente importantes no desenvolvimento das ações previstas: o Centro de Processamento de Dados (ao qual, depois de contatos iniciais, já encaminhamos, um esboço de projeto a fim de desenvolver um Sistema Integrado de Catálogos de Acervos Musicais Baianos [em diante SICAMB]) e do Instituto de Ciência da Informação, cuja presença significativa durante este ciclo de palestras, parece prometer futuras parcerias no desenvolvimento da Arquivologia Musical como disciplina acadêmica na UFBA.

Tabela 1 - Cronograma das etapas previstas no projeto

\begin{tabular}{|c|c|c|c|c|}
\hline PERIODO & 2003-2004 & 2004-2005 & 2005-2006 & 2006-2007 \\
\hline ETAPA & $\begin{array}{l}\text { Chamado de } \\
\text { atenção regional } \\
\text { e nacional }\end{array}$ & $\begin{array}{l}\text { Afirmação regional } \\
\text { e articulação federal }\end{array}$ & $\begin{array}{l}\text { Expansão } \\
\text { acadêmica } \\
\text { internacional }\end{array}$ & $\begin{array}{l}\text { Fim de uma etapa... } \\
\text { Começo de outras... }\end{array}$ \\
\hline \multirow{8}{*}{ 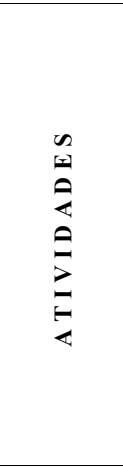 } & $\begin{array}{l}\text { Prognose } \\
\text { Arquivística. }\end{array}$ & \multicolumn{3}{|c|}{$\begin{array}{l}\text { Detecção, inventário e reprodução digital dos acervos de música mais } \\
\text { relevantes. }\end{array}$} \\
\hline & \multicolumn{4}{|c|}{$\begin{array}{l}\text { Desenvolvimento dos aspectos pedagógicos em nível terciário - Publicações, aulas, } \\
\text { palestras, orientações PIBIC, co-orientações, etc. }\end{array}$} \\
\hline & \multicolumn{4}{|c|}{$\begin{array}{l}\text { Desenvolvimento de pesquisas e projetos em Musicologia Histórica - Participação em } \\
\text { eventos nacionais e internacionais }\end{array}$} \\
\hline & & \multirow{2}{*}{\multicolumn{3}{|c|}{$\begin{array}{l}\text { Desenvolvimento do SICAMB e Inicio do Processo de Catalogação } \\
\text { em rede via Internet dos acervos de música baianos. } \\
\text { Fundamentos teóricos: Musicologia Histórica e disciplinas afins } \\
\text { (Arquivologia Musical, Edição Musical, etc.) - Convidados externos e } \\
\text { desenvolvimento de novas ferramentas. }\end{array}$}} \\
\hline & & & & \\
\hline & & & \multicolumn{2}{|c|}{$\begin{array}{l}\text { Elaboração do projeto acadêmico para a } \\
\text { Musicologia Histórica na UFBA }\end{array}$} \\
\hline & & & \multicolumn{2}{|c|}{$\begin{array}{l}\text { Homenagens e Eventos Internacionais em } \\
\text { Musicologia Histórica na Bahia }\end{array}$} \\
\hline & & & & \begin{tabular}{|l|} 
Estabelecimento \\
definitivo da \\
Musicologia Histórica na \\
Bahia
\end{tabular} \\
\hline
\end{tabular}

No nível inter-institucional, além do apoio recebido das agências nacionais e estaduais de amparo à pesquisa (CAPES, CNPq e 
FAPESB), contatos foram estabelecidos com diversos órgãos e instituições públicas ou privadas a fim de dar suporte documental aos trabalhos de pesquisa. Neste sentido cabe destacar os contatos estabelecidos em nível de governo estadual com a Fundação Pedro Calmon (diretamente ou através da Direção da Biblioteca Pública do Estado e da Sub-Gerência de Obras Raras e Valiosas, ou da Direção do Arquivo Público do Estado) ou com a Polícia Militar (com a qual temos iniciado as atividades de pesquisa e catalogação dos seus acervos musicais, com destaque para o da Banda Militar Maestro Wanderley) e Municipal com a Fundação Gregório de Mattos (especialmente através da Chefia do Setor Áudio-Visual).

No plano das outras instituições contatadas, com as quais temos iniciado trabalhos de pesquisa, catalogação e extensão, além das ações iniciadas nos acervos do Instituto Geográfico e Histórico da Bahia (IGHB) e da Fundação Instituto Feminino da Bahia (FIFB) destacam-se aquelas já iniciadas nas instituições de natureza eclesiástica (CNBB Regional Nordeste 3, Arquidiocese de São Salvador da Bahia), assim como nas diversas confrarias em atividade na Bahia.

Contatos iniciais realizados com a Casa das Filarmônicas ainda não deram os resultados esperados. Foi apresentado à Direção Administrativa e Executiva dessa instituição um projeto de parceria, envolvendo a aplicação de normas apropriadas ao tratamento arquivístico musical apoiado no princípio de respeito aos fundos ou princípio de proveniência (carência infelizmente observada no trabalho desenvolvido pela dita instituição no que diz respeito aos acervos das filarmônicas a ela vinculadas e ao banco de partituras decorrente das suas ações). O recente convênio assinado entre a mencionada instituição e a Universidade Católica de Salvador (através do seu Instituto de Filosofia e Ciências Humanas), parece não preencher tal lacuna, se levamos em consideração a noticia de 15 de julho de 2004 publicado na página web da referida ONG. O uso de termos "coleção" para designar o acervo da Banda de Música do Corpo de Bombeiros, parece confirmar a falta de uso dos princípios arquivísticos e da terminologia apropriada. ${ }^{2}$

\footnotetext{
${ }^{2}$ Cf. NOTICIARIO DA CASA DAS FILARMONICAS, Casa das Filarmônicas firma convênio com a UCSal. Disponível em $<$ http://www.casadasfilarmonicas. org.br/noticiario_0051.htm>. Acesso em: 10 de ago. 2004.
} 
Mas não perdemos a esperança que dita instituição venha, em futuro breve, quebrar o silêncio e se integrar positivamente entre os nossos parceiros.

\section{Primeira etapa do projeto - Chamado de atenção regional e nacional}

A primeira etapa, já concluída, do projeto em desenvolvimento foi articulada em três níveis de ação, a fim de chamar a atenção para o valor e a relevância ainda existente nos arquivos baianos no nível regional e nacional.

No primeiro nível de ação foi realizada a prognose arquivística relativa a música, isto é, a do reconhecimento territorial ou o mapeamento e a listagem das instituições possuidoras de fundos documentais relativos à música na Bahia.

Com relação ao mapeamento acima mencionado, o território baiano foi dividido em sete áreas (ou mesorregiões) a serem pesquisadas, visando a operabilidade do projeto e seguindo critérios espaciais geográficos. Tais áreas assim determinadas são: 1) Metropolitana de Salvador; 2) Centro-Norte Baiano; 3) Centro-Sul Baiano; 4) Nordeste Baiano; 5) Sul Baiano; 6) Vale de São Francisco da Bahia; e 7) Extremo Oeste (Fig. 1).

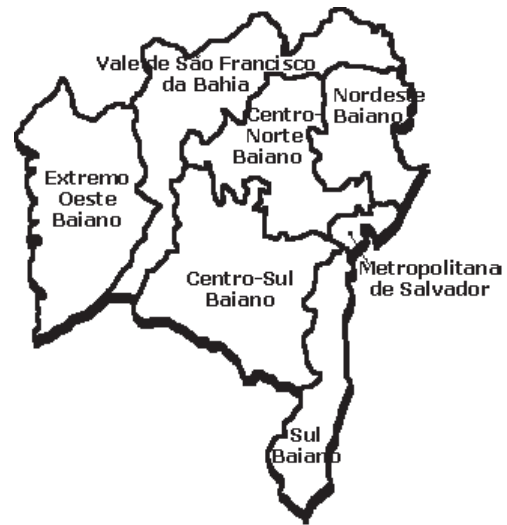

Figura 1 - Divisão do território da Bahia em mesorregiões

Devido aos processos históricos de exploração e povoamento territorial em paralelo com as características do desenvolvimento 
urbano acontecido na Bahia, o levantamento começou pela mesorregião Metropolitana de Salvador.

Em Salvador têm-se localizado vinte instituições possuidoras de acervos relativos à música, assim como um número crescente de acervos privados relacionados ao projeto (somando mais de 18 até hoje), tendo-se assim uma idéia do enorme potencial informacional que esta mesorregião apresenta, chegando hoje a ultrapassar o número de cinqüenta arquivos localizados.

Em relação ao resto do Estado, na tentativa de equacionar o tempo disponível do projeto com a superfície territorial do Estado, o levantamento inicial realizado a partir de informações relativas às filarmônicas e outras instituições vinculadas direta ou indiretamente à atividade musical formal, tanto de natureza pública ou privada, civil ou militar, laica ou religiosa, empresarial ou comunitária, enquanto naturais possuidores de acervos musicais, permite realizar uma estimativa de distribuição territorial destes acervos, o que justificaria um escalonamento das atividades a iniciar na mesorregião Metropolitana, continuando pelo Sul, Centro-Norte, Centro-Sul, Nordeste, Vale do São Francisco, para concluir no Extremo-Oeste baiano.

Ao todo, nos mais de 500 municípios baianos recenseados pelo IBGE, já foram localizados mais de 190 fundos de documentos musicais pertencentes a arquivos públicos estaduais e municipais, sociedades e associações filarmônicas civis, além das coleções privadas e dos diversos acervos bibliográficos relativos à música. Por outro lado, as informações disponibilizadas pela Secretaria de Cultura e Turismo do Estado da Bahia, relativas às festividades nos municípios baianos, permitem vislumbrar o potencial volume de documentos que, por exemplo, a prática das novenas (com ou sem procissões acompanhadas de filarmônicas) produz.

Ao todo, podemos afirmar que mais de dois mil (2000) arquivos relativos a música permanecem à espera do tratamento arquivístico necessariamente sistemático seguindo normas próprias da arquivologia e/ou da arquivologia musical.

Uma vez concluída a estimativa anterior foi iniciado um gradativo levantamento (e a conseqüente indexação, inventário e catalogação) dos seus materiais relativos a música. 


\section{Problemas encontrados}

Em termos gerais, os problemas mais comumente encontrados nos diversos acervos podem ser organizados em quatro grupos: a) condições infra-estruturais; b) condições de guarda e preservação; c) regulamentos e condições extremas de disponibilização para pesquisa e divulgação; e d) sistemas de catalogação e descrição documental utilizados.

Entre os problemas relativos às condições infra-estruturais, podem-se mencionar a falta de espaço adequado (os arquivos se encontram em prédios deteriorados ou em condições precárias de segurança); a falta de equipamentos apropriados para administração e manipulação dos documentos; a falta de orçamento dedicado por parte das autoridades responsáveis; e a falta de pessoal capacitado (atuando, em muitos dos casos, na base da boa vontade).

Em concomitância com o grupo de problemas inicialmente descrito, verificaram-se problemas relativos às condições de guarda e preservação, destacando-se a falta de cuidado em relação às condições climáticas (umidade e temperatura ambiente excessiva, possibilitando a proliferação de diversos tipos de fungos) ou falta de isolamento adequado dos ambientes (fechamentos deteriorados ou inapropriadamente abertos, impossibilitando a segura manipulação de manuscritos particularmente frágeis); o empilhamento indiscriminado de pastas horizontais (ultrapassando o peso máximo suportado por elas, ficando literalmente esmagadas umas embaixo das outras) ou verticais penduradas (muitas vezes contendo um número de documentos maior que o que a resistência dos materiais prevê); armários e prateleiras metálicos enferrujados; caixas verticais, de papelão ou plásticos (os documentos sofrem a gravidade e se amassam, ou colam as folhas por pressão).

Já em relação às carências detectadas no que diz respeito aos regulamentos e condições extremas de disponibilização para pesquisa e divulgação, pode-se indicar como mais crítica a manipulação irrestrita dos manuscritos (permitindo o acesso direto inclusive aos armários ou prateleiras) ou desconfiança excessiva (não disponibilização de documentos para pesquisa), além da falta de critério na identificação prévia do pesquisador ou visitante (ausência de reque- 
rimento de identificação do pesquisador ou solicitação desproporcionada de credenciais do pesquisador e de descrição do objeto da pesquisa).

Finalmente, é mister mencionar a falta de atualização detectada nos sistemas de catalogação e de descrição documental utilizados. Nas bibliotecas (públicas ou comunitárias) são utilizados sistemas de catalogação com um grau insuficiente de descrição dos itens processados, ressentindo-se a identificação e gestão dos documentos, inclusive no que diz respeito ao controle no uso e circulação dos documentos musicais nelas depositados. Por sua vez, nos arquivos públicos ou institucionais (como nos casos do Arquivo Histórico Municipal ou da Fundação Instituto Feminino da Bahia, por exemplo) e nas coleções privadas os sistemas chegam a ser do tipo sui generis, apresentando problemas semelhantes ao caso das bibliotecas.

\section{Soluções propostas}

A partir do reconhecimento dos problemas gerais detectados, podem-se propor as seguintes soluções: a) melhora qualitativa das condições de guarda e preservação; b) melhora ergonômica das condições humanas e infra-estruturais; c) adoção de sistemas de catalogação e descrição documental adequados; e d) desenvolvimento e aplicação de regulamentos e condições criteriosas de disponibilização para pesquisa e divulgação.

Na procura de melhorar qualitativamente as condições de guarda e preservação, o controle da umidade, da temperatura ambiente e da luminosidade dos ambientes com janelas fechadas, com auxilio de aparelhos controladores da umidade ambiente, ar condicionado regulado e iluminação "fria", seriam indispensáveis. Tais condições existem apenas no Centro de Documentação (CEDOC) da Empresa Gráfica da Bahia (EGBA) e vêm se estabelecendo definitivamente na Biblioteca Central da UFBA. O uso de armários metálicos inoxidáveis com número suficiente de gavetas horizontais de pouca profundidade permitiria alocar as pastas de papel neutro ou alcalino envolvendo os documentos em condições adequadas.

A melhora ergonômica das condições humanas e infra-estruturais, envolvendo a aquisição de equipamentos informáticos apropri- 
ados para consulta das bases de dados (que também deveriam ser disponibilizadas pela Internet) e, eventualmente, das imagens digitalizadas dos documentos; a definição de orçamentos dedicados a manutenção, restauro e pesquisa; e a capacitação do pessoal pelo estabelecimento de parcerias entre a UFBA e a instituição envolvida, pelo sistema de estímulo e incentivo.

Com relação aos sistemas de catalogação e descrição documental utilizados nas Bibliotecas, arquivos públicos e acervos privados, no que diz respeito aos documentos musicais, está sendo proposta e discutida aqui a utilização do sistema de catalogação tipo RISM conjuntamente com as normas de descrição tipo $\operatorname{ISAD}(\mathrm{G})$, com adaptações semelhantes às propostas pelo nosso colega, o Prof. André Guerra Cotta, na sua dissertação de mestrado em Ciência da Informação (COTTA, 2000), ou às utilizadas no Museu da Música de Mariana, no Museu da Inconfidência, ou parcialmente no Acervo Curt Lange da UFMG, o que permitirá uma certa padronização do formato das informações disponíveis no Brasil.

Finalmente, no que diz respeito aos regulamentos e condições de disponibilização para pesquisa e divulgação, sugerimos o estabelecimento de formulários de solicitação prévia à visita expondo os motivos da consulta e uma identificação do pesquisador (institucional, profissional, etc.) minimamente suficiente; a manipulação controlada dos manuscritos (quando concluída a digitalização, só deveria ser autorizado o acesso aos documentos reais para estudos muito específicos e absolutamente necessários e justificados). Caso o pesquisador venha a solicitar a reprodução de documentos, poderia ser cogitada a fixação de uma taxa a ser cobrada por conceito de reprodução de imagens, via uma tabela pré-fixada de valores.

Se os problemas não forem passíveis de soluções definitivas e adequadas, procurar-se-ão soluções temporárias, podendo envolver, inclusive, processos de reelaboração digital ou eletrônica de partituras (editoração) nos casos de músicas ainda funcionais, com o indesejado, mas eventualmente necessário "deslocamento" estritamente temporário dos documentos para o lugar com condições adequadas mais próximo do local de origem da documentação. Neste sentido, elaboramos e apresentamos à Fundação Pedro Calmon um projeto de parceria (amparado no Convênio amplo já assinado entre dita 
Fundação e a UFBA) com a finalidade de estabelecer um Centro de Documentação Musical da Bahia, que ainda se encontra em estudo por parte daquela instituição.

\section{Segunda etapa do projeto - Afirmação regional e articulação federal}

Nesta segunda etapa, iniciada há poucos meses, o objetivo denominado "Afirmação regional e articulação federal" propende à multiplicação das ações desenvolvidas pelo projeto e dos seus colaboradores.

Neste sentido, as atividades iniciadas e desenvolvidas em cada local possuidor de fundos documentais incluem as seguintes:

a) entrevista com os responsáveis institucionais ou particulares pelo acervo em questão procurando saber sobre a história do acervo (gênese, aquisição, etc.), a função que tem e/ou teve para a comunidade que usufrui dele, em algum momento, e os objetivos e finalidades que ao seu respeito foram estabelecidas pela instituição ou particular;

b) entrevista com os encarregados/funcionários diretamente vinculados ao acervo em questão, verificando a existência de algum tipo de catálogo, inventário, lista ou semelhante, ao tempo de coletar outras informações relativas à história do acervo (pesquisadores que o utilizaram, visitaram, consultaram, etc.);

c) definição dos limites do acervo à procura de uma localização adequada do seu conteúdo;

d) identificação dos fundos documentais que o constituem, estabelecendo como prioridade o levantamento daqueles que possuem partituras (manuscritas ou impressas);

e) catalogação dos fundos documentais seguindo as prioridades já estabelecidas;

f) digitalização das partituras e de outros documentos relativos à música que sejam relevantes e/ou raros;

g) estudo e divulgação dos mesmos articulando tais atividades sob diversas formas, com destaque para as eletrônicas, entre as quais se destaca a edição crítica de texto musical em formato de hipertexto, cuja idealização e desenvolvimento está sendo realizada. 
Já iniciadas as atividades anteriormente descritas em grande parte dos acervos localizados na capital e em municípios do Recôncavo Baiano (Maragogipe, Cachoeira, Santo Amaro, por exemplo), pretende-se articular a pesquisa dos municípios restantes através de três ações fundamentais:

a) estabelecer um convênio com as instituições competentes nas áreas musical e social (profana e/ou religiosa) visando o aproveitamento de estruturas e prestígio entre as organizações musicais da Bahia, para estabelecer uma rede de contatos socialmente responsáveis que serão treinados para realizar o levantamento dos acervos de música do Estado, geralmente localizado em instituições como filarmônicas, corais, etc., de caráter familiar e cujas tradições na Bahia se remontam aos tempos coloniais. Segundo constatamos em arquivos localizados em Cachoeira, elas foram muitas vezes receptoras dos repertórios sacros que perderam a sua funcionalidade durante a primeira metade do século XX, preservando parte da memória musical sacra da região. A idéia básica é treinar agentes multiplicadores que, colocando-se à frente de cada comunidade cultural, seriam treinados ao tempo em que receberiam equipamentos e condições para irem alimentando as bases de dados necessárias a uma primeira etapa, que denominamos de inventário ou pré-catalogação.

c) sensibilizar as autoridades eclesiásticas e governamentais (estaduais e/ou municipais) a fim de procurar estabelecer uma situação semelhante à ação anterior no que diz respeito aos arquivos e acervos de música locados nessas instituições no interior do Estado;

d) procurar os financiamentos ou parcerias necessárias para a melhor guarda, preservação e administração do patrimônio assim identificado, envolvendo nesta tarefa tanto as forças políticas, quanto as sociais e empresariais de cada local e município.

Tais ações já estão sendo articuladas. Para tais efeitos, projetos e solicitações tem sido encaminhadas e estão sendo analisadas pelas autoridades competentes em cada caso, tanto internamente na UFBA, quanto em forma inter-institucional. 


\section{Breve descrição do SICAMB}

O Sistema Integrado de Catálogos de Acervos Musicais Baianos (SICAMB), segundo foi mencionado acima, foi apresentado na forma de esboço preliminar ao Centro de Processamento de Dados da UFBA (CPD-UFBA) a fim de desenvolvê-lo em parceria com o nosso projeto, levando em consideração as normas internacionais para a catalogação descritiva de documentos musicais (impressos ou manuscritos) desenvolvidas pelo grupo RISM adaptado à realidade arquivística e musical documental brasileira; adaptações já incorporadas, por exemplo, na base de dados desenvolvidas pelo Prof. André Guerra Cotta para o Museu da Música de Mariana, fato pioneiro no Brasil.

O fato de adotarmos um padrão internacional como o RISM (único na sua categoria e que completou o seu primeiro meio século de existência em 2002) não configura apenas uma medida de natureza política. É, antes de tudo, uma decisão estratégica no que diz respeito as atualizações conceituais na área, colocando o SICAMB em igualdade de condições com as bases de dados mais importantes do mundo, ao tempo em que, se tudo acontecer no tempo certo, seria o primeiro sistema on-line dessa natureza a ser desenvolvido no Brasil.

A segunda grande inovação que propõe o SICAMB é a inserção de dados à distância, via Internet. Contando com um treinamento prévio e com ajuda de formulários que seriam disponibilizados de maneira gradativa segundo avançam as etapas desde o inventário preliminar até completar a catalogação definitiva, o responsável pelo ingresso de dados de um arquivo relativo a música numa localidade determinada, não precisaria sair da própria cidade, nem do próprio local do arquivo para realizar a tarefa. Isto permitiria, não apenas poder obter uma relação clara do universo documental relativo a música em tempo mínimo, mas garantir a permanência dos documentos no seu local original, sem deslocamentos desnecessários, mantendo assim a unidade documental e respeitando a memória e o patrimônio musical da referida localidade baiana. Tanto o ingresso quanto o controle dos dados ingressados por nossa parte, aconteceria desde qualquer ponto de Internet, tendo níveis de acesso e segurança garantidos por senhas e outros dispositivos. 


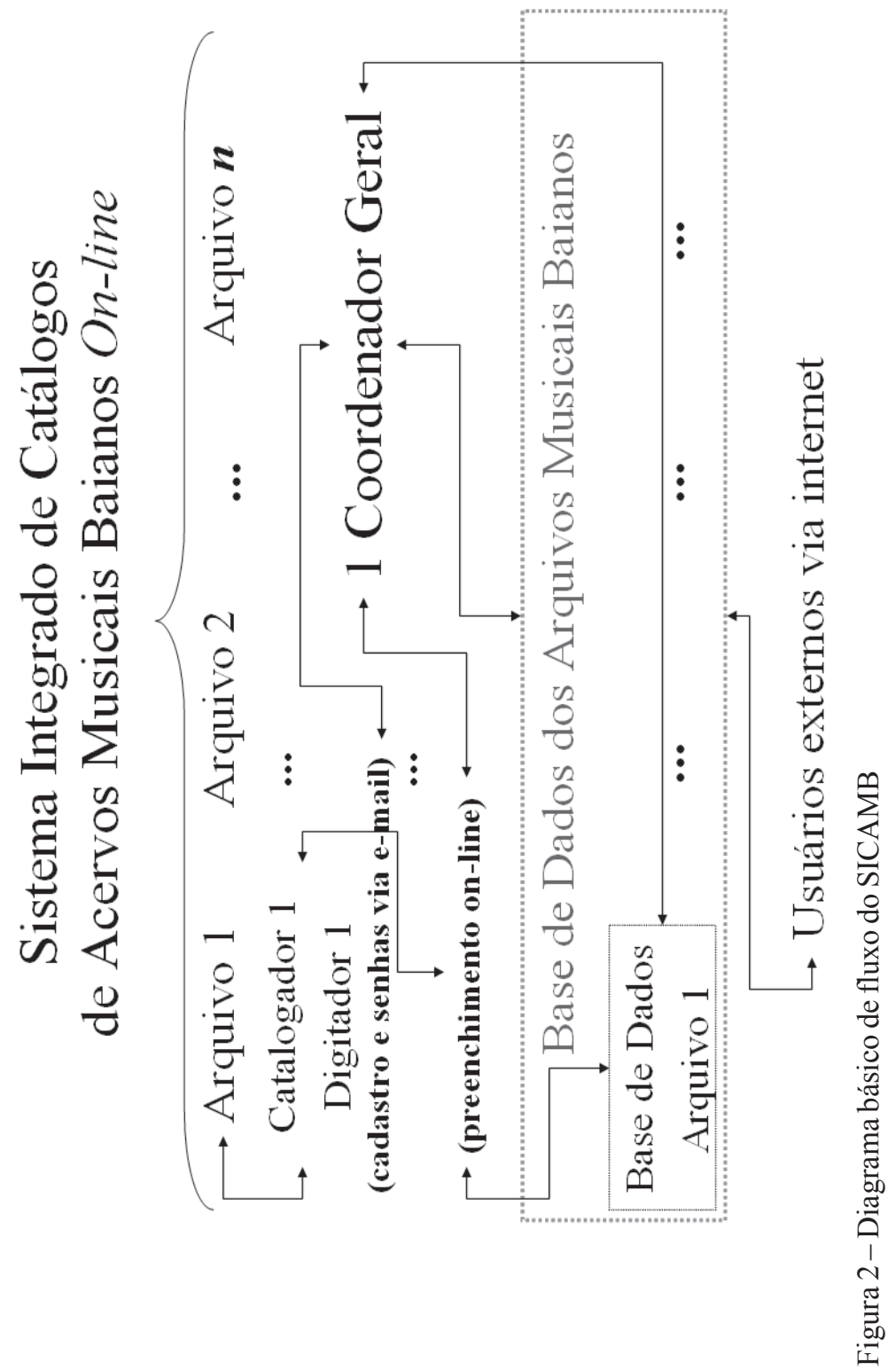


À guisa de exemplo a Figura 3 apresenta o diagrama que resultaria se o SICAMB fosse utilizado desde um arquivo histórico diocesano localizado na Arquidiocese de Feira de Santana, sendo o processo controlado desde o PPGMUS-UFBA em Salvador.

Esperamos em breve ter avançado na implementação deste sistema, sempre em parceria com o CPD-UFBA a fim de desenvolver o SICAMB no âmbito estritamente acadêmico universitário.

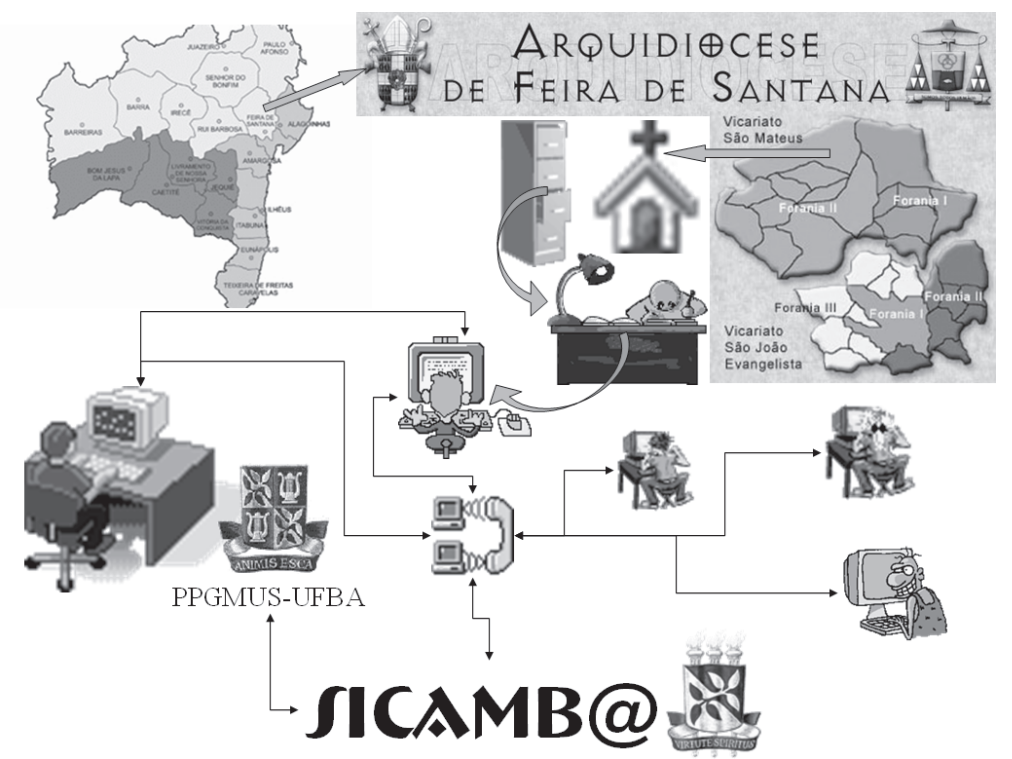

Figura 3 - Diagrama exemplificando o funcionamento do SICAMB pela Internet

\section{Outros aspectos e atividades desenvolvidas}

Além de tudo o já exposto até aqui, desde o início do projeto "O Patrimônio Musical na Bahia" se desenvolvem atividades pedagógicas (tanto em nível terciário quanto de pós-graduação) e de pesquisa em musicologia histórica, focando assuntos relevantes ainda não estudados com a necessária profundidade (como o caso do repertório das novenas em Salvador e no Recôncavo Baiano) ou assuntos com pesquisas incompletas ou abandonadas (como a dos nossos vultos histórico-musicais, exemplificados aqui nos casos de 
Damião Barbosa de Araújo, João Manoel Dantas, Domingos da Rocha Mussurunga, Manoel Tranquillino Bastos, entre outros).

O projeto permite ainda a realização de outras atividades tais como a publicação de documentos musicais relevantes, colaborar com outras pesquisas concomitantes cujo alvo musicológico se encontre na Bahia (ou a ela esteja de alguma forma vinculado), participar em eventos nacionais e internacionais, promover o desenvolvimento de ferramentas e metodologias necessárias, assim como o estabelecimento de estratégias inter-institucionais através da elaboração de projetos estratégicos, podendo acrescentar, finalmente, a disponibilidade para fornecer assessoria no que diz respeito a assuntos inerentes ao projeto, isto é, relativos à musicologia histórica, à arquivologia musical, à edição e editoração musical, assim como outras atividades conexas.

\section{Resultados esperados}

Entre os resultados esperados, além daqueles inerentes aos objetivos específicos do projeto, podemos destacar o resgate da memória cultural e musical histórica baiana, o reaquecimento do interesse e envolvimento da comunidade baiana com os aspectos musicais da sua história, a valorização do passado histórico musical e cultural baiano, assim como o fortalecimento das relações comunitárias-acadêmicas-governamentais através da organização de seminários, eventos, palestras, e/ou publicações decorrentes do projeto. 


\section{Referências Bibliográficas}

COTTA, André Guerra. O tratamento da informação em acervos de manuscritos musicais brasileiros. 2000. 291 folhas. Dissertação (Mestrado em Ciência da Informação). Escola de Biblioteconomia, Universidade Federal de Minas Gerais, Belo Horizonte, 2000.

KIEFER, Bruno. História da Música Brasileira: dos primórdios ao início do século XX. Porto Alegre: Movimento, 1976. 140 p.

NEVES, José Maria. Arquivos de manuscritos musicais brasileiros: breve panorama. In: SIMPÓSIO LATINO-AMERICANO DE MUSICOLOGIA, 1., 1997, Curitiba. Anais... Curitiba: Fundação Cultural de Curitiba, 1998. p.137-163.

NOTICIARIO DA CASA DAS FILARMÔNICAS. Casa das Filarmônicas firma convênio com a UCSal. 15 jul. 2004. Disponível em: <http://www.casadasfilarmonicas.org.br/noticiario_ 0051.htm>. Acesso em: 10 ago. 2004. 


\section{Acervo Curt Lange - UFMG: apresentação e perspectivas}

André Guerra Cotta

\section{Introdução}

Este trabalho, que encerra a nossa participação no Ciclo de Palestras Arquivologia e Patrimônio musical, pretende fornecer uma visão geral sobre o arquivo pessoal do musicólogo teuto-uruguaio Francisco Curt Lange, o chamado Acervo Curt Lange - UFMG, com informações sobre o histórico de sua formação, suas principais características e suas futuras perspectivas. A título de introdução, apresentaremos uma nota biográfica sobre Curt Lange, para situar o leitor menos familiarizado com a sua figura e dar subsídios ao entendimento do objeto do trabalho.

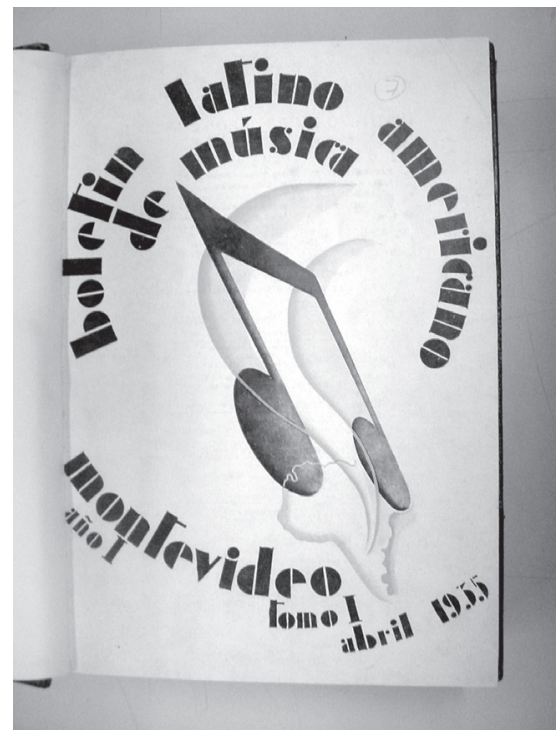

Figura 1: Capa do Tomo I do Boletin Latino Americano de Música (1935) 
Nascido em Eilenburg, Alemanha, em 12 de dezembro de 1903, com o nome Franz Kurt Lange, o musicólogo veio para a América do Sul em 1923, inicialmente por Buenos Aires (Argentina), radicandose logo depois em Montevidéu (Uruguai), onde se naturalizou, adotando o nome de Francisco Curt Lange, e se casou, em 1928, com Maria Luíza Vertiz Lange. A sua atividade foi desde o início diversificada, atuando como pedagógo, professor, animador cultural, editor e até mesmo como representante comercial de instrumentos musicais, mas destacou-se sobretudo o seu trabalho de pesquisa musicológica na América Latina, desde os anos trinta do século passado, quando iniciou um movimento conhecido como Americanismo Musical. Lange fundou em Montevidéu o Instituto Interamericano de Musicologia, através do qual publicou, entre 1935 e 1946, o Boletin Latinoamericano de Musica, com seis volumes. Foi editor de outros periódicos da área de música, como a Revista de Estudios Musicales (Mendoza, Argentina) e a Revista Musical de Venezuela (Caracas, Venezuela).

A partir de meados de 1944, Lange passou a dedicar-se à pesquisa sobre a música brasileira do período colonial, particularmente em Minas Gerais. Através de pesquisa de campo e de contatos com bandas e famílias de músicos nas cidades do interior de Minas, Lange reuniu centenas de antigos manuscritos de música, através dos quais provou a existência de uma atividade musical até então insuspeitada, nas Minas Gerais dos séculos XVIII e XIX. A grande repercussão das publicações de Lange sobre a música mineira e - maior ainda da notícia de seus achados históricos, as antigas partes manuscritas de música, levaram a muita controvérsia, chegando até mesmo à abertura, em 1967, de um processo no Conselho Federal de Cultura, que teve como um de seus resultados a criação da lei 5.471, de 9 de julho de 1967, proibindo a exportação de acervos documentais dos séculos XVI a XIX, inclusive "quaisquer originais e cópias antigas de partituras musicais" (MASSARANI, 1968). Embora tivesse muitos detratores, Lange tinha também defensores importantes, inclusive em cargos públicos. Em 1973, dois números do Suplemento Literário do Diário Oficial do Estado de Minas Gerais, foram dedicados a Curt Lange, intitulados Lange, o Descobridor, contendo depoimentos de personalidades do meio intelectual e acadêmico da época, 
coordenados por Rui Mourão, que em 1990 publica um ensaio biográfico sobre Lange, acompanhado de uma tradução para o português de seu artigo do Boletín de 1946: "La música en Minas Gerais: un informe preliminar".

Muitos trabalhos de caráter biográfico sobre Lange foram publicados em diversas línguas, ${ }^{1}$ mas o seu complexo percurso biográfico e a sua atuação diversificada, somados ao fato de que Lange teve uma longa e produtiva vida, encerrada com seu falecimento em 1997, aos 94 anos de idade, portanto, fazem com que uma biografia suficientemente abrangente sobre a figura de Francisco Curt Lange necessite de um esforço coletivo de pesquisa, abrangendo um âmbito geográfico e institucional.

O legado documental deixado por ele encontra-se principalmente no Brasil2: em 1983, depois de décadas de tensão e acusações, veio finalmente para Brasil a coleção de manuscritos musicais que reuniu a partir de 1944, passando para a custódia do Museu da Inconfidência de Ouro Preto, onde ficou conhecida como Coleção Francisco Curt Lange; em 1995, o seu arquivo pessoal foi doado à UFMG, passando a chamar-se Acervo Curt Lange. É provável que, depois das considerações feitas nos dias anteriores deste evento, se possa utilizar a terminologia arquivística sem o risco de uma interpretação interconceitual de conceitos como arquivo e coleção, mas convém ressaltar que é totalmente diferente a natureza dos dois acervos mencionados, ainda que se relacionem.

\section{O Acervo Curt Lange - UFMG}

Em 1995, o arquivo pessoal de Francisco Curt Lange foi doado pela VITAE e pelo BDMG Cultural à Universidade Federal de Minas Gerais, sendo então transferido de Caracas (Venezuela) para a Biblioteca Universitária da UFMG, em Belo Horizonte (MG), Bra-

\footnotetext{
${ }^{1}$ Dentre os quais podemos destacar o ensaio de Luiz Merino Montero, "Francisco Curt Lange (1903-1997): Tributo a un americanista de excepción" (MERINO MONTERO, 1998).

${ }^{2}$ Fazemos esta ressalva porque é possível que partes de seu acervo tenham eventualmente ficado nas muitas instituições em que trabalhou, em cidades como Mendoza (Argentina) e Caracas (Venezuela).
} 
sil). A recepção do material foi oficialmente marcada com uma Exposição de documentos organizada pelo BDMG Cultural e por um Simpósio Internacional de Musicologia, que contou com a participação de várias autoridades da área, e com a presença do próprio Lange.

Constituído por uma grande quantidade e variedade de materiais, o arquivo passou a ser objeto de um trabalho sistemático de tratamento realizado por equipe interdisciplinar a partir de 1999, quando foi denominado naquela instituição como Acervo Curt Lange (ao qual passaremos a nos referir como ACL-UFMG ou simplesmente $\mathrm{ACL}$ ). Devido à natureza arquivística da maior parte do material, o seu tratamento técnico representou, inicialmente, um grande desafio do ponto de vista metodológico, pois, de maneira geral, a instituição esteve encarregada da custódia de material bibliográfico, cujo tratamento, como já vimos, baseia-se em princípios e técnicas muito diferentes daqueles preconizados pela arquivologia

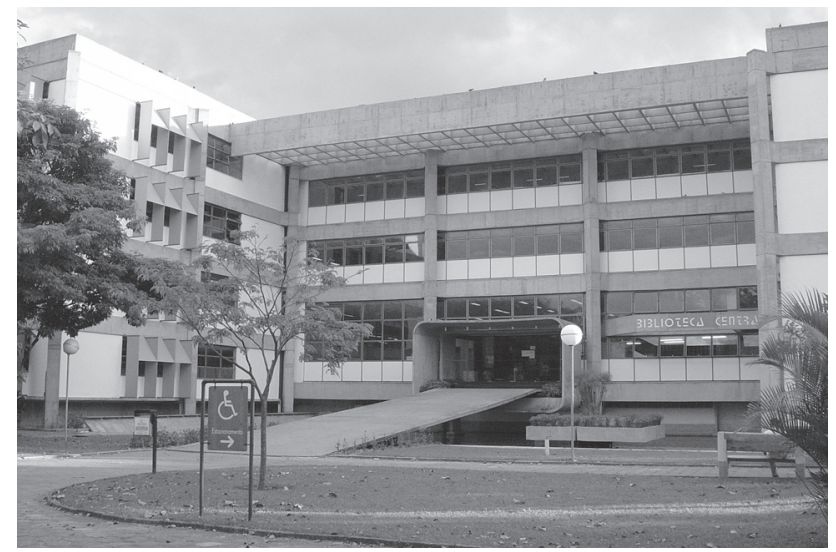

Figura 2: Fachada da Biblioteca Universitária da UFMG

Como já tivemos a oportunidade de ver em momentos anteriores neste ciclo de palestras, a diferença fundamental entre os tratamentos arquivístico e bibliográfico consiste justamente na observação, por parte do primeiro, do já mencionado princípio de respeito aos fundos ou princípio de proveniência, enquanto as técnicas de tratamento voltadas para material bibliográfico baseiam-se em critérios abstratos, podendo ser temáticos, alfabéticos, cronológicos, sem observar a proveniência, o contexto e o processo de acumulação do 
material documental. A aplicação indiscriminada de tais critérios para o tratamento de material arquivístico pode representar danos irreparáveis em termos de recuperação da informação ${ }^{3}$ e acesso à documentação.

No caso do ACL-UFMG, uma feliz convergência de especialistas permitiu que se aplicassem as metodologias adequadas a cada material, de acordo com a sua natureza. A instalação do Acervo Curt Lange na Biblioteca Universitária deu-se através de um longo processo. Inicialmente restrito a ações pontuais, este processo intensificou-se a partir de 1999, quando tiveram início ações sistemáticas e articuladas de intervenção, com vistas ao arranjo e descrição do material. Depois de sucessivas intervenções e estudos interdisciplinares envolvendo musicólogos, bibliotecários, especialistas em arquivologia e profissionais da área de Ciência da Informação, estabeleceu-se um quadro de arranjo com treze séries documentais, em alguns casos divididas em subséries, de acordo com as características da documentação, de modo que em pouco tempo o acervo já dispunha de um inventário (TUGNY, 2002).

A página web do ACL-UFMG (<http://www.bu.ufmg.br/ clange $>$ ) contém uma relação bastante detalhada de tais ações, sobre as quais podemos dizer que se fizeram com base nas recomendações da teoria arquivística, partindo do nível mais geral - o fundo arquivístico em sua totalidade - para os mais específicos, as séries, subséries, em alguns casos chegando à descrição ao nível de item documental.

O quadro de arranjo estabelecido revela a diversidade de materiais existentes no ACL-UFMG, contidos nas diferentes séries documentais. A Série 1 - Coleção Bibliográfica, divide-se em sete subséries: 1.1 - Obras de Referência; 1.2 - Monografias; 1.3 - Periódicos; 1.4 - Separatas; 1.5 - Folhetos; 1.6 - Libretos de ópera e 1.7 Publicações de Curt Lange.

\footnotetext{
${ }^{3}$ Utilizamos o termo recuperação tal como cunhado por Calvin Mooers em 1951 (information retrieval, no original inglês), ou seja, para designar o acesso à informação em sistemas de comunicação (ARAÚJO, 1994, p. 85).
} 


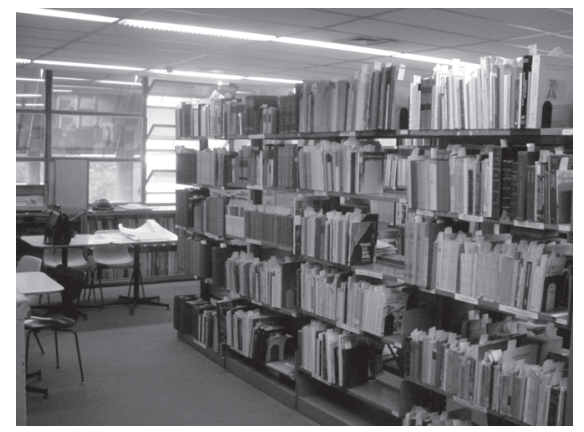

Figura 3: Série 1 - Coleção Bibliográfica.

A figura 3 mostra uma visão parcial da Subsérie 1.1 - Obras de referência. Esta foi a primeira subsérie documental a ser efetivamente tratada, inclusive por se constituir por material de natureza bibliográfica.

Totalmente diferente da Série 1, a Série 2 - Correspondência é de natureza claramente arquivística e constitui-se de duas subséries, tal como organizadas pelo próprio Lange: Subsérie 2.1 - Correspondência Enviada, composta de aproximadamente 58.880 itens documentais cronologicamente organizados; Subsérie 2.2 - Correspondência Recebida, composta por 2565 pastas, contendo aproximadamente 70.000 itens documentais, organizados por países e remetentes (em alguns casos, organizou os dossiês por critérios temáticos e por cidades, ordenando alfabeticamente por remetente). Trata-se de material acumulado pelo musicólogo ao longo de suas atividades entre 1931 e 1995, originais e cópias em papel carbono de toda a correspondência enviada e recebida por ele, trocada com interlocutores de expressão nas esferas artística e científica do século XX.

As duas subséries foram mantidas na ordem original dada pelo próprio Lange, com pequenos ajustes. A descrição das duas subséries foi realizada de maneira diferente, devido às suas características: enquanto o arranjo dado à Subsérie 2.2 permitiu sua descrição por dossiê, no caso da Subsérie 2.1 foi necessária a descrição ao nível de item documental, para que se pudesse, inclusive, localizar cada destinatário. 


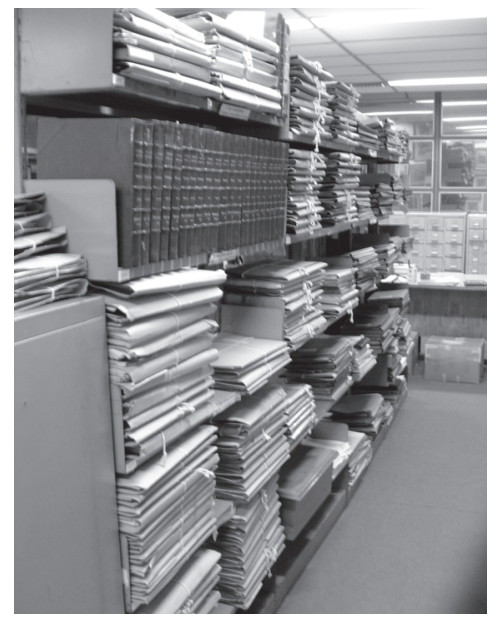

Figura 4: Subsérie 2.1 - Correspondência enviada

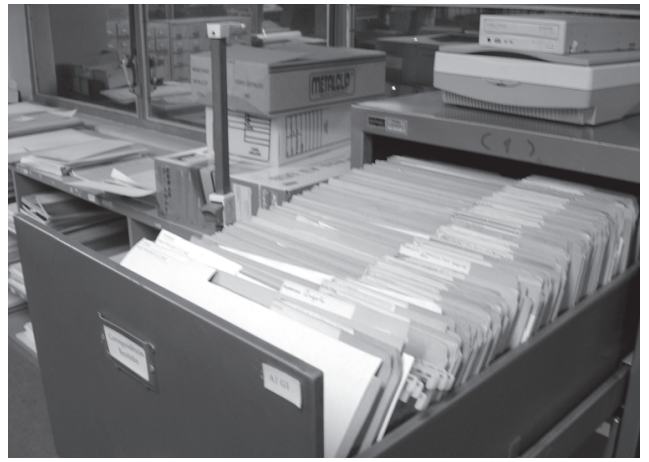

Figura 5: Subsérie 2.2-Correspondência recebida

Assim como a Série 2, é também de natureza arquivística a Série 3 - Vida, constituída por documentos pessoais, materiais de trabalho, recortes de jornal, diários, etc., acumulados por Lange entre 1923 e 1994, disposta em 894 dossiês, contendo aproximadamente 7000 itens (Figura 6).

A Série 4 - Partituras é uma das séries que contém fontes especificamente musicais e contitui um dos casos mais complexos do ACL. Ressalte-se que o tratamento de fontes musicais é uma atividade que exige conhecimentos específicos de música para que se possa garantir um resultado razoavelmente coerente - excetuan- 
do-se, talvez, o material publicado, que pode ser abordado bibliograficamente.

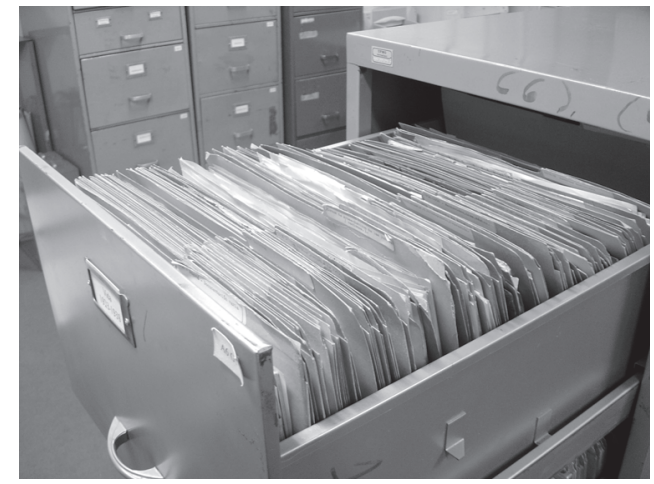

Figura 6: Série 3 - Vida

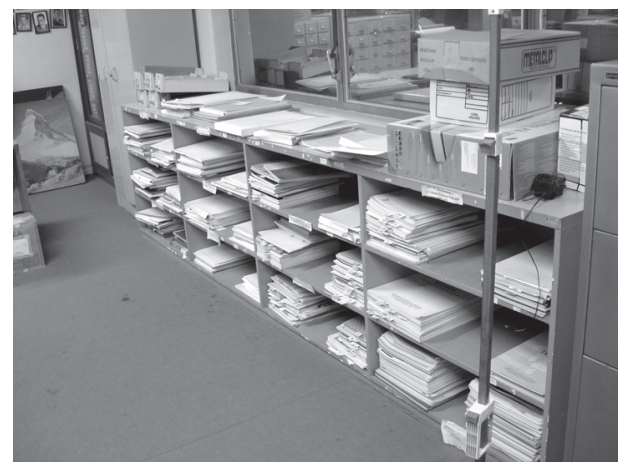

Figura 7: Série 4- Partituras

Fazem parte da Série 4 a Subsérie 4.1 - Originais e cópias de manuscritos musicais, subsérie que comporta cópias reprográficas de manuscritos musicais, em sua maioria de obras do século XX (com apenas duas exceções que são efetivamente de manuscritos), em 46 dossiês; a Subsérie 4.2 - Partituras publicadas por Curt Lange, que contém as publicações da Editorial Cooperativa Interamericana de Compositores e a coleção "Compositores Contemporâneos da Venezuela”, entre outras dirigidas por Curt Lange, totalizando 29 itens; e finalmente a Subsérie 4.3 - Partituras publicadas (por terceiros), que reúne partituras publicadas por editores diversos e é constituída por 198 itens. 
Ocorre que esta série não contém a totalidade das partituras ou partes musicais existentes no ACL, embora reúna a maioria delas. Um importante material referente aos trabalhos de restauração (ou, segundo a terminologia mais apropriada, edição) de música brasileira dos séculos XVIII e XIX efetuados por Curt Lange encontra-se na Subsérie 10.5 - Transcrições e Restauro de Manuscritos Musicais e também um conjunto de reproduções de partes musicais de Domenico Zipoli está incluído na Subsérie 10.6 - Domenico Zipoli. Estas subséries relacionam-se hierarquicamente com a Serie 10 Documentos de Pesquisa. Além disso, a Subsérie 8.1 - Fotografias (que integra a Série 8 - Iconografia) contém centenas de reproduções fotográficas de partituras encontradas nos arquivos históricos, principalmente de Minas Gerais. Como se trata de diferentes suportes, não seria o caso de questionar o arranjo dado, mais sim de buscar soluções para a acessibilidade destes diferentes documentos musicais, de incluir, junto aos registros relativos à Série 4 - Partituras referências àqueles itens que, embora sejam também partituras (ou partes), pela lógica do arranjo permaneceram em outras séries ou subséries às quais organicamente pertencem.

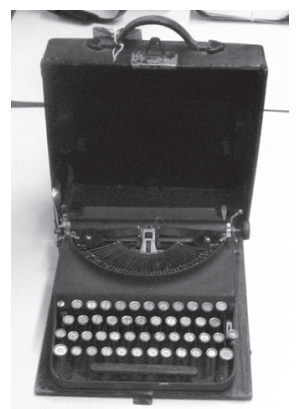

Figura 8: Máquina datilográfica Remington, pertencente à Série 6 Instrumentos de trabalho

O ACL-UFMG tem outras séries que interessam diretamente como fontes para a pesquisa e para a educação musical, como a Série 7 - Registros audiovisuais, que contém LPs, CDs, fitas-cassete, fitas magnéticas e fitas em VHS, e a já mencionada Série 8 Iconografia, que contém, além de fotografias, quadros, slides, 
microfilmes e negativos. ${ }^{4}$ A Subsérie 8.1 - Fotografias, como já mencionado anteriormente, contém muitas reproduções de documentos dos séculos XVIII e XIX, inclusive de manuscritos musicais.

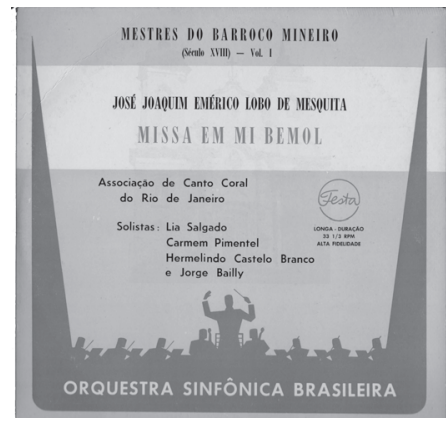

Figura 9: LP pertencente à Série 7 - Registros audiovisuais

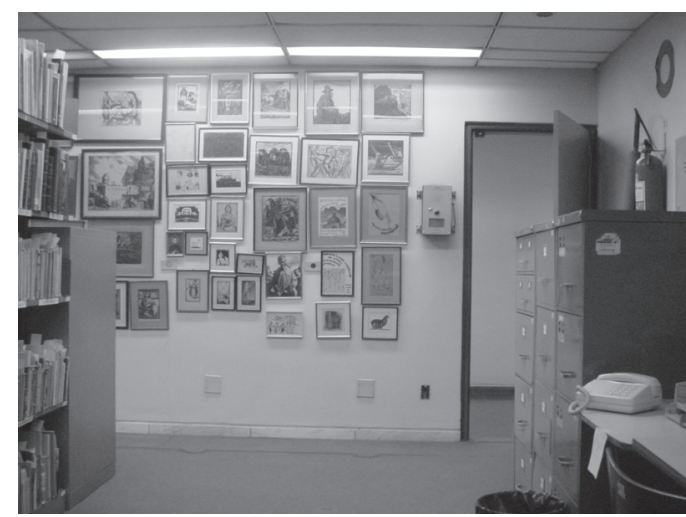

Figura 10: Série 8-Iconografia

Destacam-se ainda a Série 9 - Documentos Raros, que contém originais manuscritos de arquivos históricos, como petições, recibos, relações, etc., produzidos entre os séculos XVII e XIX. Uma de suas subséries, a Subsérie 9.2 - Documentos manuscritos de arquivos históricos está sendo totalmente digitalizada e será disponi-

\footnotetext{
${ }^{4}$ Não é o objetivo deste trabalho apresentar todas as séries do ACL-UFMG, mas apenas fornecer um referencial para o leitor, mencionando alguns exemplos, que poderão posteriormente ser por ele explorados. Para mais informações sobre o acervo, suas séries e sobre o próprio processo de tratamento, sugerimos a visita à página do ACL-UFMG, no URL < http://www.bu.ufmg.br/clange>.
} 
bilizada para a toda a comunidade de pesquisa na página web, em arquivos JPG, como mostra a Figura $11 .^{5}$

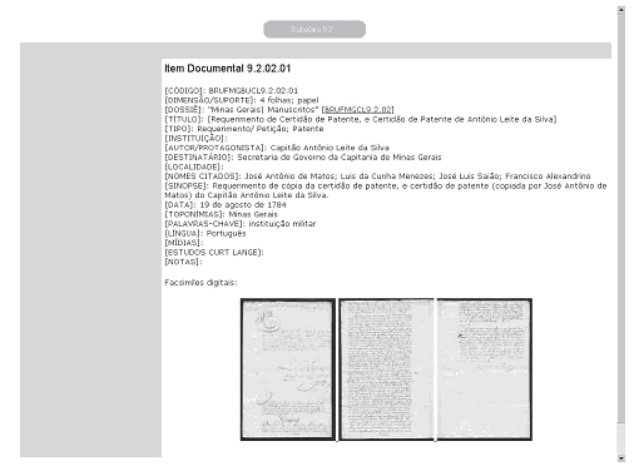

Figura 11: Fac-símiles da Série 9 - Documentos raros, na página Web do ACL-UFMG.

A Série 10 - Documentos de Pesquisa, talvez uma das mais significativas para o estudo da obra musicológica de Curt Lange, é constituída pelas Subséries 10.1 - Biobibliografia, ${ }^{6} 10.2$ Miscelánea; 10.3 - Estudos e transcrições de documentos de arquivos históricos; 10.4 - Artigos e estudos avulsos recebidos de pesquisadores; 10.5 - Transcrições e restauro de manuscritos musicais; 10.6 - Domenico Zipoli; 10.7 - Manuscritos avulsos de Curt Lange; 10.8 - Listagens; 10.9 - Exemplos musicais; 10.10 - Recortes da imprensa; 10.11 - Documentos de programações musicais; 10.12 - Catálogos e folders. A Figura 12 mostra os dossiês em que Lange deixou o material intitulado por ele próprio como "Miscelánea", que hoje constituem a Subsérie 10.2 do ACL-UFMG. Assim como os dossiês da Subsérie 2.1, eles são abertos lateralmente, de modo que os documentos neles contidos permanecem sujeitos à ação da poeira, insetos e outros agentes naturais.

\footnotetext{
${ }^{5}$ A disponibilização em meio digital desta subsérie está sendo realizada através de projeto realizado em convênio FAPEMIG/UFMG/FUNDEP, intitulado Tratamento arquivistico e disponibilização de informações em meio digital no Acervo Curt Lange - UFMG, em andamento.

${ }^{6}$ A Subsérie Biobibliografia é constituída por fichas, manuscritos, correspondências, recortes, biografias e cronologias, nas quais Curt Lange reuniu inúmeras informações biográficas sobre compositores e músicos, relacionadas a um projeto que deixou inacabado: um Léxico Latino-Americano de Música.
} 


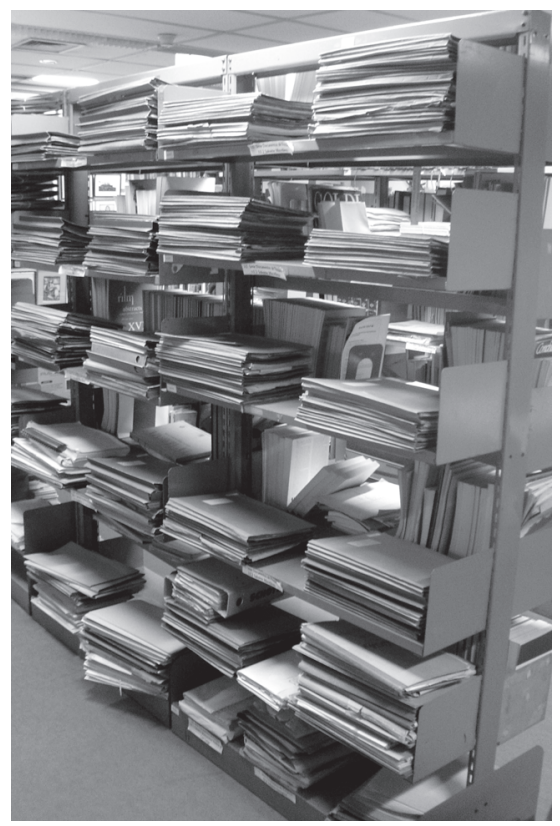

Figura 12: Série 10 - Documentos de Pesquisa, Subsérie 10.2 - Miscelánea

\section{ACL-UFMG - Perspectivas}

Desde o início dos trabalhos de tratamento arquivístico do ACLUFMG, dos quais participaram diversos profissionais, ${ }^{7}$ uma das grandes preocupações tem sido com a utilização de mobiliário e equipamentos adequados com relação, sobretudo, à conservação dos documentos. Não foram poucos os projetos enviados a diversas agências de fomento, muitas vezes sem sucesso, apesar dos esforços, o que por vezes colocava em dúvida o futuro do acervo, as perspectivas de preservação e conservação, principalmente dos materiais mais ex-

\footnotetext{
${ }^{7}$ Não mencionaremos nominalmente neste breve relato todos estes profissionais, alunos e professores, até mesmo para não cometer alguma injustiça. Mas não seria justo deixar de mencionar a importante e dedicada participação da Prof. Rosângela Pereira de Tugny, da Escola de Música - UFMG, no sentido de viabilizar e coordenar, entre 1999 e 2004, uma série de projetos que permitiram o tratamento gradual do ACL-UFMG, em uma perspectiva interdisciplinar, arrojada, que viabilizaram a efetiva instalação do acervo na UFMG.
} 
postos ou mais sensíveis. As figuras 4 e 12 mostram como as pastas que acondicionam as Subséries 2.1 e 10.2 são abertas, permitindo a entrada de agentes naturais que contribuem para a deterioração do suporte dos documentos, como detalha a Figura 13.

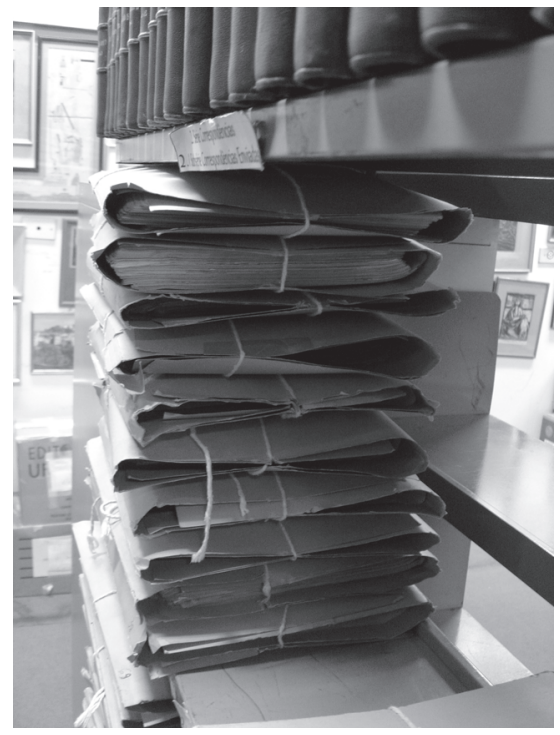

Figura 13 - Aspecto de dossiês da Subsérie 2.1, com aberturas laterais.

Outras subséries também sofrem com o tipo de acondicionamento para elas utilizado há décadas, como se pode ver pelas Figuras 5 e 6 , que mostram como o próprio peso dos documentos pressiona as pastas suspensas nas gavetas da Subsérie 2.2 ou da Série 3. Já as partituras, embora tenham sido reacondicionadas recentemente em envelopes de papel alcalino, continuam enfrentando problemas: o próprio papel alcalino não resistiu à ação da poeira e do manuseio, como mostram as figuras 14 e 15.

As perspectivas se modificaram muito com a feliz notícia da aprovação pelo Programa Petrobras Cultural do projeto Conservação e Instalação Definitiva do Acervo Curt Lange - UFMG, que será realizado no decorrer de 2005 . O projeto viabilizará, além de uma página web trilíngüe para o ACL (português, espanhol e inglês) e um guia impresso (também trilíngüe), a sua instalação definitiva. 

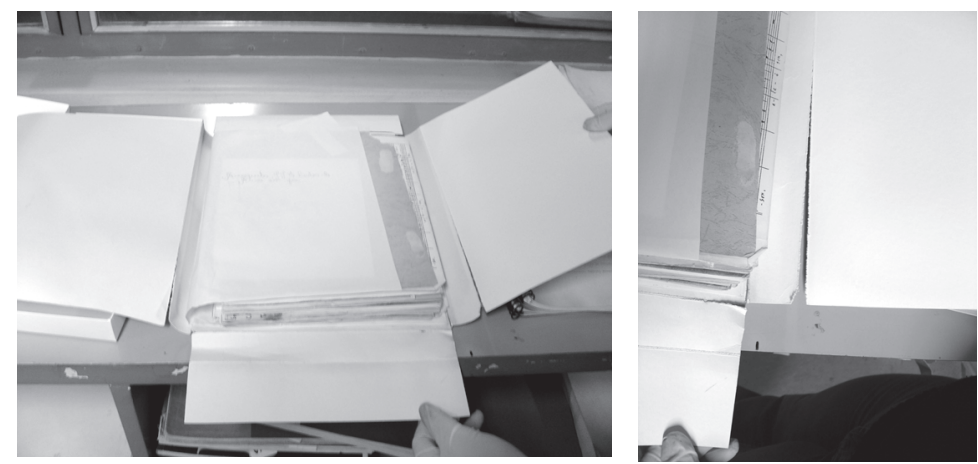

Figuras 14 e 15 - Aspectos dos envelopes usados para as partituras

O projeto viabilizará a aquisição de mobiliário adequado - incluindo um arquivo deslizante - e equipamentos de informática, todo o material para o tratamento técnico com vistas à conservação, a cargo do CECOR-UFMG. ${ }^{8}$ Para dar um exemplo, além de todo um processo de tratamento e limpeza, os documentos serão acondicionados em caixas de papel alcalino, especialmente desenhadas, como mostram as Figuras 16 e 17.
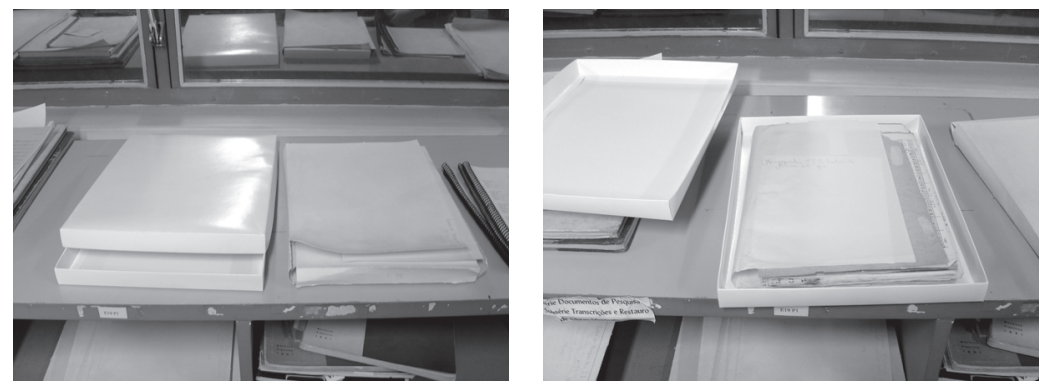

Figuras 16 e 17 - Ilustração das caixas de papel alcalino.

${ }^{8} \mathrm{O}$ referido projeto foi elaborado conjuntamente pelo conservador Mario Sousa Júnior, do CECOR-UFMG, e pelo autor deste trabalho, contando com apoio da Prof. a Rosângela Tugny, da EM-UFMG, da Chefe de Coleções Especiais da BUUFMG, Marlene Vieira Lopes e da Diretora da Biblioteca Universitária da UFMG, Simone Aparecida dos Santos, além do inestimável apoio da instituição proponente, a FUNDEP - Fundação de Desenvolvimento da Pesquisa. 
A Biblioteca Universitária da UFMG já disponibilizou para o ACL-UFMG uma nova sala com 172 metros quadrados (cerca de três vezes a área da sala atualmente ocupada pelo acervo), que permitirá a disposição adequada do mobiliário e dos equipamentos, além da realização de exposição permanente de documentos do acervo.

As novas perspectivas, contudo, trazem uma grande responsabilidade, na medida em que obriga a própria instituição a estruturar uma política de atendimento à comunidade, uma vez que o acervo será divulgado para um público maior e em âmbito geográfico mais amplo. Outros desafios se colocam no horizonte, como a necessidade de sistematização dos procedimentos relacionados à propriedade intelectual, a sistematização do atendimento a pesquisadores de outros países e até mesmo uma política de estabelecimento de preços de reprodução digital de documentos para fins de pesquisa. Neste sentido, a orientação da equipe hoje a cargo do tratamento técnico do ACL-UFMG está em consonância com as recomendações do III SLAM, recentemente ratificadas no I Colóquio Brasileiro de Arquivologia e Edição Musical (Mariana, julho de 2003).

Procuramos, assim, dar ao nosso ouvinte/leitor informações gerais e imagens do ACL-UFMG, de maneira que ele possa conhecer minimamente sua história, seu conteúdo e algumas das questões técnicas que envolvem o seu tratamento. Finalmente, deixo as coordenadas para aqueles que quiserem entrar em contato com a equipe do acervo, convidando a todos a buscarem mais informações na página web do ACL (<http://www.bu.ufmg.br/clange>), que será futuramente reelaborada, como dissemos. 
Acervo Curt Lange - UFMG (ACL-UFMG)

Biblioteca Universitária da UFMG - $4^{\circ}$ Andar Av. Antônio Carlos, 6627

CAMPUS Pampulha

Belo Horizonte - MG

CEP 31270-010

tel. (31)3499-4419

Email: clange@bu.ufmg.br 


\section{Referências bibliográficas}

ARAÚJO, V.M.R.H. de. Sistemas de recuperação da informação SRIs. In: Sistemas de recuperação da informação. Rio de Janeiro: 1994. Capítulo 5, p. 84-121.

MASSARANI, Renzo. O descobrimento das partituras que desapareceram. Fatos e fotos. Rio de Janeiro, n. 392, 8 ago. 1968.

MERINO MONTERO, Luis. Francisco Curt Lange (1903-1997): tributo a un americanista de excepción. Revista Musical Chilena, Santiago, v. 52, n. 189, p. 9-36, ene. 1998. Disponível em: <http:// www.scielo.cl/scielo.php?script=sci_arttext\& pid=S0716$27901998018900002 \& \operatorname{lng}=$ pt\&nrm=isso $>$. Acesso em: 01 out. 2004.

MINAS GERAIS. Diário Oficial de Minas Gerais. Curt Lange - O descobridor - I. Minas Gerais, Suplemento Literário (org. Rui Mourão). Belo Horizonte, Imprensa Oficial, $n^{\circ}$ 355, ano VIII, 16 jun. 1973, 12 p.

MINAS GERAIS. Diário Oficial de Minas Gerais. Curt Lange - O descobridor - II. Minas Gerais, Suplemento Literário (org. Rui Mourão). Belo Horizonte, Imprensa Oficial, $n^{0}$ 356, ano VIII, 23 jun. 1973, 12 p.

TUGNY, Rosângela Pereira de. O inventário do Acervo Curt Lange da UFMG: contribuições para uma ética da pesquisa de campo em musicologia. In: ENCONTRO DE MUSICOLOGIA HISTÓRICA, 4., Juiz de Fora, 2000. Anais... Juiz de Fora: Centro Cultural PróMúsica; Rio de Janeiro: Fundação Biblioteca Nacional, 2002. p. 262276. 
Este livro foi publicado no formato $148,5 \times 210 \mathrm{~mm}$ Miolo em papel $75 \mathrm{~g} / \mathrm{m}^{2}$

Tiragem: 500 exemplares

Impresso no Setor de Reprografia da EDUFBA

Acabamento: ESB Serviços Gráficos 